\title{
Azerbaycan'ı Zafere Götüren Büyük Taarruz: 44 Günlük Savaşın Anatomisi
}

\section{The Great Offense That Led Azerbaijan to Victory: The Anatomy of the 44-Days War}

\author{
Ali Asker ${ }^{1} @$, Zeynep Gizem Özpınar ${ }^{2}$ ๑(
}

${ }^{1}$ Ali Asker (Öğr. Üyesi, Doç. Dr.), Karabük Üniversitesi, İktisadi İdari Bilimler Fakültesi, Uluslararası Ilişkiler Bölümü, Karabük, Türkiye. E-posta: aliasker2068@gmail.com ORCID: 0000-0003-1801-3371

\footnotetext{
${ }^{2}$ Sorumlu yazar/Corresponding author: Zeynep Gizem Özpınar (Yüksek Lisans Öğrencisi)، Karabük Üniversitesi, Lisansüstü Eğitim Enstitüsü, Bölge Çalışmaları Anabilim Dalı, Karabük, Türkiye. E-posta: zeynepgizemozpinar@gmail.com ORCID: 0000-0002-3240-649X

Başvuru/Submitted: 22.12 .2020 Kabul/Accepted: 19.02.2021

Atıf/Citation: Asker, Ali ve Ozpınar, Zeynep Gizem. " Azerbaycan'ı Zafere Götüren Büyük Taarruz: 44 Günlük Savaşın Anatomisi." Avrasya incelemeleri Dergisi - Journal of Eurasian Inquiries 10, 1 (2021): 83-106.

https://doi.org/10.26650/jes.2021.004
}

\section{ÖZ}

Kafkasya, yakın coğrafyamızda yer alan ve jeopolitik-jeostratejik, siyasi, tarihi ve sosyolojik yönüyle son derece önemli bir bölgedir. Sadece coğrafi anlamda değil sosyolojik yönüyle de bu bölgede gelişen olaylar güvenlik ve birçok nedenden dolayı Türkiye'yi de yakından etkilemektedir. Kafkasya'da yer alan devletler arasındaki ilişkiler, çevre ülkelerinin bölgeye yönelik politikaları ve uluslararası alanda yaşanan gelişmeler; bölge güvenliğini, istikrarı ve refahı ciddi şekilde etkileyebilmektedir. 19. yüzyılda Rusya tarafından işgal edilmiş bu bölgede 20. yüzyılın başlarında üç bağımsız cumhuriyet -Gürcistan, Azerbaycan ve Ermenistan- ortaya çıkmışsa da 2-2,5 yıl varlıklarını devam ettirebilmiş bu cumhuriyetler yeniden Sovyet Rusya'sı tarafından işgal edilmişlerdir. Gerek bağımsızlık döneminde gerekse sonraki aşamalarda komşu ülkelerin topraklarını işgal ederek genişleme politikasına yönelen Ermenistan, değişik tarihi süreçlerde fırsat buldukça Azerbaycan'dan toprak kopararak kendi sınıllarına dâhil etmiştir. Azerbaycan'da Sovyet hâkimiyeti tesis edildikten sonra Zengezur bölgesi Ermenistan'a verilmiş, ayrıca Karabağ'ın dağlık bölgesinde Ermenilere özerklik tanınmıştır. Fakat Ermenistan bununla yetinmeyerek her firsatta Azerbaycan'a karşı toprak iddialarını gündeme getirmiştir. Sovyetler Birliğínin dağılması sürecinde yeniden harekete geçen Ermenistan bu kez silahlı yönteme başvurmuş, savaş yoluyla Azerbaycan topraklarının yaklaşık \%20'sini işgal etmiştir. Çeyrek asırdan fazla süredir Dağlık Karabağ bölgesi ve çevresini işgal altında tutan Ermenistan sorunun barış̧̧ıl çözümüne ilişkin her türlü öneriyi geri çevirirken Azerbaycan'ın diğer bölgelerine yönelik yeni saldırılarda bulunmuştur. 2020'de Ermenistan ordusunun savaş hazırlıkları ve bu bağlamda gerçekleştirdiği yeni saldırlar ikinci bir Karabağ savaşının kaçınılmaz olduğunu ortaya koymuştur. Ermenistan'ın saldırılarına karşı Azerbaycan ordusunun düzenlediği büyük taarruz 44 gün boyunca sürmüştür. Bu savaşta büyük hezimete uğrayan Ermenistan ordusu, sonunda Rusya-Azerbaycan-Ermenistan tarafından yapılan üçlü bildiri gereğince teslimiyeti kabul ederek Azerbaycan topraklarından çekilmiştir.

Anahtar kelimeler: Azerbaycan, Ermenistan, Karabağ, Savaş, Üçlü Bildiri 


\begin{abstract}
By virtue of its close proximity, the Caucasus is extremely important to Turkey in geopolitical/geostrategic, political, historical, and sociological terms. Events in this region, both geographically and sociologically speaking, closely affect Turkey for security and other reasons. Relations between the states in the Caucasus, the policies of surrounding countries toward the region, and developments in the international arena can seriously affect the security, stability, and prosperity of the region. At the beginning of the 20th century, the collapse of imperial Russia allowed three independent republics-Georgia, Azerbaijan, and Armenia-to emerge in this region. These states were able to survive for only 2-2.5 years before they were again occupied by Soviet Russia. Armenia, which adopted an expansionary policy by occupying the territories of neighboring countries both in this period of independence and thereafter, took land from Azerbaijan and incorporated it within its borders through various historical processes. After Soviet rule was established in Azerbaijan, Zangezur region was given to Armenia, and autonomy was granted to Armenians in the mountainous region of Karabakh. Armenia was not satisfied with this, however, and raised territorial claims against Azerbaijan at every opportunity. Armenia pursued a similar policy during the dissolution of the Soviet Union, but this time resorted to armed conflict and occupied about 20\% of Azerbaijan's territory. Armenia, having occupied Nagorno-Karabakh and surrounding areas for more than a quarter of a century, rejected any proposal for a peaceful resolution to the problem and made new attacks on other regions of Azerbaijan. By 2020, the Armenian army's preparations for war and the new attacks carried out in this context indicated that a second Karabakh War was inevitable. The Great Offensive organized by the Azerbaijani army against the attacks of Armenia lasted for 44 days. The Armenian army, which suffered a significant defeat, eventually withdrew from the territory of Azerbaijan, accepting the surrender in accordance with the trilateral declaration between Russia, Azerbaijan, and Armenia.
\end{abstract}

Keywords: Azerbaijan, Armenia, Karabakh, War, Tripartite Declaration

\title{
EXTENDED ABSTRACT
}

The Caucasus region is of particular geopolitical significance to Turkey. This area, and its Turkish and Muslim inhabitants in particular, has long had close relations with Turkey, and it has thus been included within the scope of Turkey's geopolitical interests. In terms of the population of the region, Azerbaijani Turks constitute an important part. Although Turkey's military activity in the region grew significantly at the beginning of the 20th century, the Turkish army was forced to leave after the Armistice of Mudros.

During the period of Soviet domination, Turkey had no political, economic, or other relations with the South Caucasus countries. For their part, these countries were completely dependent on Moscow and had no authority to conduct foreign affairs. Moreover, Turkey was a NATO member state in the Western bloc of the bipolar system. After the collapse of the Soviet Union, Turkey developed political, economic, and cultural policies for the region. In this context, relations with Azerbaijan developed quickly and reached an advanced stage in a short time, leading to a high-level strategic partnership. Georgia, another important state in the region, also agreed to participate in important projects alongside Turkey and Azerbaijan. Armenia did not respond positively to Turkey's tolerant and neighborly policy, and instead maintained a hostile attitude toward Turkey. Armenia, which had territorial claims against Azerbaijan, later pursued these claims through war and occupied Karabakh, long Azerbaijani territory, and seven surrounding regions. 
After a ceasefire was signed in Bishkek in 1994, Armenia violated its terms repeatedly and rejected proposals for a peaceful resolution of the dispute. Although four resolutions $(822,853$, 873, and 884) were adopted by the UN Security Council in relation to the conflict, the OSCE Minsk Group, which was formed to resolve the matter, remained completely ineffective. The ceasefire was again seriously violated in April 2016 as a result of Armenian attacks, and after four days of fighting, the Azerbaijani army was able to save some important positions from Armenian occupation. This skirmish demonstrated the strategic and tactical capabilities of the Azerbaijani army. When the Armenian army attacked Tovuz, a border area, a great reaction was provoked in Azerbaijan as this is an extremely important area through which energy infrastructure is routed. Although Armenia sought to draw the Collective Security Treaty Organization into the war by using this conflict as an excuse, it was unable to achieve this. Subsequently, certain intelligence information was obtained that Armenia was preparing for a new attack, that the ceasefire would be violated, and that a new conflict would begin. In light of this information, while the Azerbaijani army continued its preparations for war, President Ilham Aliyev declared that his country would respond harshly to any attack by Armenia.

Upon the attack of the Armenian army on September 27, 2020, the Azerbaijani army began its great offensive. Azerbaijani counterattacks surprised the Armenian army and inflicted great losses in a short time. On the first day, 12 Armenian air defense systems were destroyed, and, as a result of attacks involving helicopters and drones, Armenian forces were forced to retreat, abandoning important positions. In the following days, Armenian losses mounted, a situation that Prime Minister Pashinyan and other high-level Armenian officials attempted to hide in their statements. In addition, the Armenian government made incriminating claims against Azerbaijan and Turkey and requested international assistance, most notable from Russia. Armenia was unsuccessful in its diplomatic overtures to international organizations and major states and was gradually forced to leave important positions in the occupied territories one by one. In this 44-day war, the Armenian side suffered significant losses and was eventually obliged to sign the tripartite declaration of November 10, 2020 proposed by Russia. In line with the agreement, while Russian peacekeeping forces were established in predetermined regions, the Armenian army withdrew from the territories it formerly occupied.

Although the Turkish army did not participate in direct military intervention and armed conflict during the war, it provided great support to Azerbaijan technologically and, even more importantly, by offering diplomatic counsel. This support provided very strong assurance to Azerbaijan. Although Armenia's incriminating claims against Turkey (e.g., the participation of Turkish soldiers in the war, the transfer of jihadist groups from the Middle East to the region, etc.) remain unconfirmed, Armenia's targeting of civilian settlements throughout the war has had serious repercussions. Various comments have been made by researchers and regional experts about how matters will unfold. After emerging victorious from the war, Azerbaijan shows maximum determination to protect its own interests. 


\section{GİRIŞ}

1980'lerin ortalarında Sovyetler Birliği'nde başlatılan “perestroyka ve glasnost” politikasını fırsat bilen Ermeniler Azerbaycan'a karşı eski iddialarını ileri sürerek, Dağlık Karabağ Özerk Vilayeti'nin Ermenistan'a katılması talebini gündeme getirmişlerdir. Kısa süre sonra bunun yanlış bir karar olduğunu fark ederek taktik değiştiren Ermeniler, Dağlık Karabağ Ermenilerinin self-determinasyon hakkını gündeme getirmiş ve bağımsızlık talebinde bulunmuşlardır. Bu gelişmeler sonucunda meydana gelen uyuşmazlıklar zamanla, Moskova yönetiminin doğrudan ve dolaylı desteği ile derinleşmeye başlamıştır. 1980’lerin sonlarına gelindiğinde Ermenistan Cumhuriyeti'nin Türk/Müslüman ahalisi büyük baskı ve şiddet altında yurtlarından edilmişlerdir.

İlerleyen dönemde Karabağ'da her geçen gün genişleyen çatışmalarda çok sayıda Azerbaycanlı sivil insan öldürülmüş, esir alınmış ve yurtlarından kovulmuşlardır. 1992'de Ermeniler tarafından 20. yüzyılın en kanlı cinayetlerinden olan Hocalı Soykırımı yapılmıştır. Devam eden süreçte Dağlık Karabă̆'ın çevresinde yedi bölge de Ermenistan tarafindan işgal edilmiştir. Birleşmiş Milletler Güvenlik Konseyi’nin Azerbaycan’ın yoğun diplomatik çabaları sonucunda almış olduğu dört karar uygulanmazken, çözüm sürecini yürüten AGİT Minsk Grubu'nun faaliyetlerinden de olumlu sonuç alınamamıştır. 1994'te Bişkek Protokolü'nün imzalanmasından bu yana, Ermenistan tarafı ateşkes rejimini sürekli ihlal etmiş, sivilleri hedef almış, masum insanların hayatına kast etmiştir. Bu süreçte Ermenistan'a destek veren devletlerin başında sorunun çözümüyle uğraşması gereken Minsk Grubu eş başkanları gelmektedir. ABD, Rusya ve Fransa bu işgalci devlete açık veya dolaylı yoldan destek sağlarken, topraklarını işgalden kurtarmaya çalışan Azerbaycan üzerinde baskı kurarak sürekli tehdit dili kullanmışlardır. Saldırgan ve mağdur arasında fark gözetmeyerek her ikisine eşit muamelede bulunan, hatta saldırganı destekleyen bu devletler pek çok konuda birbirileri arasında çıkar çatışması yaşarken, Azerbaycan-Ermenistan savaşı söz konusu olunca ortak tutum sergileyebilmişlerdir. Bunun nedeni, sadece o ülkelerde bulunan diaspora ve lobi teşkilatlarının yoğun faaliyetleriyle açıklanamaz. Bu güçlerin nazarında güçlü bir Azerbaycan, Kafkasya'da güçlü bir Türkiye demektir. ABD’nin Kafkasya ile yakından ilgilendiği dönemlerde bile Rusya'nın tahakkümü altında bulunan Ermenistan'a destek vermesinin mantıklı açıklamasını bulmak son derece zordur. Azerbaycan topraklarının \%20'sini işgal eden Ermenistan ateşkes süreci boyunca kendisine yöneltilen barış önerilerini açık veya dolaylı şekilde geri çevirmiştir. Ermenistan, ateşkesi fırsat bilerek çatışmayı dondurulmuş hale getirmeye, Azerbaycan halkının azim ve ümitlerini tüketmeye ve Karabağ'ın işgalini unutturmaya çalışmıştır. Çeyrek asır devam eden statükonun özeti bundan ibaretti. Azerbaycan ise herhangi bir şekilde geri adım atmayacağını, eğer sorun barış yoluyla çözülmezse, bunu askeri güç kullanarak topraklarını işgalden kurtaracağını defalarca beyan etmiştir. Bu çizgi Azerbaycan'ın iç ve dış siyasetinde kesintisiz şekilde devam ettirilmiştir. Otuz yıl kadar devam eden bu süre zarfında, Azerbaycan muasır standartlara cevap veren bir ordu kurarak yüksek düzeyde savunma teknolojileriyle donatmış, subay ihtiyacını karşılamak için gereken önlemleri almıştır. 
Azerbaycan ve Ermenistan arasındaki ateşkes sürecinde üç önemli kırılma yaşanmıştır. Bunlardan birincisi 2016'da, 2 Nisan'da başlayıp 5 Nisan'da sona eren 4 Gün Savaşı (veya Nisan Dövüşleri)'dır. Bu savaş Azerbaycan ordusunun başarılı taarruz kabiliyetinin sergilendiği çok önemli bir muharebedir. İkinci kırılma 12-18 Temmuz 2020'de, Ermenistan'ın Tovuz'a saldırısıyla yaşanmıştır. Dağlık Karabağ ile bağlantısı bulunmayan ve Azerbaycan-Ermenistan sınırında yer alan bu bölgeye yapılan saldırı dünya kamuoyunda da büyük yankı uyandırmıştır. Saldırı sırasında Azerbaycan ordusundan birkaç asker, astsubay, subay ve General Polad Haşimov şehit edilmiştir. Saldırının ardından Azerbaycan'da vatandaşlar sokaklara dökülerek, Azerbaycan yönetiminden harekâta başlama talebinde bulunmuşlardır. Üçüncü ciddi kırılma ise 27 Eylül 2020'de, Ermenistan'ın saldırısı ve Azerbaycan ordusunun karşı taarruz harekâtıyla yaşanmıştır. 44 gün devam eden bu savaşta büyük kayıplar veren Ermenistan, yenilgiyi kabul ederek Azerbaycan topraklarından çekilmek zorunda kalmıştır.

\section{1. "NISSAN DÖVÜŞLERİ": 4 GÜN SAVAŞI (2-5 NİSAN 2016)}

Azerbaycan ve Ermenistan arasında 1994 yılından beri devam eden ateşkes sürecinin en ciddi ihlali 2-5 Nisan 2016 yılında gerçekleşen savaş sonucunda yaşanmıştır. Şunu da belirtelim ki 1994'den beri devam eden ateşkes sürecinde pek çok ihlal ve ufak çaplı çatışmalar yaşanmışsa da "4 Günlük Savaş", boyutu ve sonuçları itibariyle öncekilerden çok farklı olmuştur. Bu sıcak çatışmaya paralel olarak medya ve sosyal medyada da müthiş bir propaganda savaşı yaşanmıştır. ${ }^{1}$ Çatışmanın 31 Mart-1 Nisan 2016 tarihlerinde, her iki ülke liderlerinin Nükleer Güvenlik Zirvesi'nde bulundukları sırada gerçekleşmesi dikkat çekmiştir. Minsk Grubu eş başkanları kayıp ve yaralıların olmasından kaygı duyduklarını ifade ederek, tarafların güç

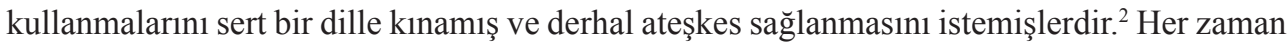
olduğu gibi yine AGİT Minsk Grubu yapıcı bir tutum sergilememiş, tarafların suçluluğunu eşitleyici bir bakış açısıyla hareket etmiştir.

Bu savaştaki en yoğun çatışmalar 2 Nisan'da gerçekleşmiştir. Ermeni mevzilerine hızlı ve yoğun bir taarruzda bulunan Azerbaycan ordusu, Talış köyü (Terter bölgesinde) dahil olmak kaydıyla, düşman kontrolündeki sekiz mevkii ele geçirmiştir. Fakat süreç içerisinde Talış köyü yeniden Ermenilerin eline geçmiştir. Azerbaycan Savunma Bakanı, 3 Nisan günü, Ermeni birliklerinin Azerbaycan yerleşim yerlerinden çekmeleri ve saldırıyı sonlandırmaları isterken, aksi takdirde Hankenti'nin vurulacağını bildirmiştir. Ermenistan ise Azerbaycan'daki doğal gaz ve petrol boru hatlarına saldırı düzenleyeceğini açıklamıştır. Aynı gün Azerbaycan, tek taraflı bir ateşkes açıklamasında bulunsa da çatışmalara ara verilmemiştir. Azerbaycan'ın

1 Turgut Kerem Tuncel, Karabăg’da Yaşanan “4 Gün Savaşı”nın Kısa Bir Değerlendirmesi. Yorum No: 2016/21, https:// avim.org.tr/tr/Yorum/KARABAG-DA-YASANAN-4-GUN-SAVASI-NIN-KISA-BIR-DEGERLENDIRMESI, 14.04.2016, (Erişim Tarihi: 18.01.2021).

2 Gülnare Mahmudova, “Arabuluculuk Diplomasisi Bağlamında AGİT Minsk Grubu’nun Başarısız Eylemi Başarılı Söylemi: Dağlık Karabağ Sorununa İlişkin 2-5 Nisan 2016 Tarihleri Arasındaki Açıklamaların Söylem Çözümlemesi”, TURAN-SAM Uluslararası Bilimsel Hakemli Dergisi, Sayı: 42 (2019) (ss. 207-215), s. 210. 
bu hareketi taktik bir hamle olarak görülmüştür. 4 Nisana gelindiğinde, çatışma bölgesine yakın bir alanda bulunan Ermeni köylerinin tahliye edildiğine ilişkin haberler yayımlanmıştır. Azerbaycan tarafı bir kayıt yayınlamış ve bu kayıtta çok sayıda Ermeni subayının öldürüldüğü ve Karabağ' daki Ermeni karargâhının imha edildiği belirtilmiştir. ${ }^{3}$ 2-5 Nisan tarihlerindeki yoğun çatışmaların ilki Azerbaycan tarafının tek taraflı ilan ettiği, fakat karşı tarafın ihlal ettiği iki ateşkes ilanı sonunda ancak durdurulabilmiştir. ${ }^{4}$

Her zaman olduğu gibi bu sefer de Ermeni medyası Azerbaycan'a yönelik asılsız suçlamalarda bulunmuş, Azerbaycan ordusunun başarılı taarruzunu dünya kamuoyunun gözünden düşürmek maksadıyla türlü yalanlar uydurmuştur. Ermeni medyası 50-60 IŞID militanının Azerbaycan ordusuna katılmak üzere temas hattına doğru ilerlediğini yazmış, Azerbaycan askerleri tarafından Ezidi asıllı bir Ermeni askerin kafasının kesildiğine ilişkin iddialar ortaya atımıştır. Azerbaycan Cumhurbaşkanı İlham Aliyev'i hedef alan Ermenistan basını yolsuzluk, despotik yönetim, insan hakları ihlalleri gibi konuları gündeme getirmiş, savaşın Azerbaycan tarafından başlatıldığını, bunun altında yatan nedenin ekonomik durgunluk ve siyasi baskı ortamında gelişen toplumsal muhalefeti başka bir düşmana yönlendirerek sönümlendirmek olduğunu yazmıştır. ${ }^{5} \mathrm{Bu}$ tür haber ve yorumlar Ermenistan'a herhangi bir fayda sağlamamış ve 4 Gün Savaşı Ermenistan ordusunun yenilgisiyle sonuçlanmıştır. Bu savaş aynı zamanda muhtemel bir savaşta Ermenistan ordusunun daha büyük kayıplar vereceğinin habercisi olmuştur. Rusya'nın başını çektiği Kolektif Güvenlik Anlaşması Örgütü’nün (KGAÖ) desteğini almak için Ermenistan'ın gösterdiği çabalar hiçbir sonuç vermezken, savaşın mali yükü Ermenistan'ın sosyo-ekonomik durumunu daha da kötüleştirmiştir. ${ }^{6}$

Savaş sırasında düşmanın 320'den fazla askeri öldürülmüş, 500'den fazlası ise yaralanmıştır. Ermeni ordusuna ait 30 tank ve diğer zırhlı araçlar, 25'den fazla top kullanılamaz hale getirilmiştir. Savaş sırasında birçok önemli mevzii Azerbaycan'ın kontrolüne geçmiştir. Terter'e bağlı Talış köyü çevresindeki hakim tepeler, Cebrayıl'ın Leletepe yüksekliği ve Çocuk Mercanlı, Goranboy'un Gülistan köyü ve Terter'in Sukavuşan (Madagiz) köyü istikametindeki bazı mevziiler düşmandan temizlenmiş, böylece"geçilmez Ermeni siperleri” miti yerle yeksan edilmiştir. ${ }^{7}$ Bu mevziilerin geri alınması ve düşman güçlerinin büyük zayiat vermesi Azerbaycan ordusunun moralini yükseltirken ülke genelinde bir coşku selinin yaşanmasına neden olmuştur. Savaş sırasında Rusya’nın pasifliği, ABD’nin kayıtsızlığı, İran'ın fırsat kovalaması

3 Turgut Kerem Tuncel, “Güney Kafkasya'da...., s.

4 Nazim Cafersoy, “4 Gün Savaş1” ve Bölgesel Dengeler, https://www.dw.com/tr/4-gün-savaş-ve-bölgeseldengeler/a-19168839, 06.04.2016, (Erişim Tarihi: 09.12.2020).

5 Turgut Kerem Tuncel, Karabağ’da Yaşanan “4 Gün Savaşı”nın Kısa Bir Değerlendirmesi, https://avim.org.tr/ tr/Yorum/KARABAG-DA-YASANAN-4-GUN-SAVASI-NIN-KISA-BIR-DEGERLENDIRMESI, 14.04.2016, (Erişim Tarihi: 08.12.2020); Turgut Kerem Tuncel, “Güney Kafkasya'da 2-5 Nisan 2016' da Yaşanan 4 Gün Savaşı”, Ermeni Araştırmaları, Sayı: 53 (2016) (ss. 301-338), s.303.

6 Nazim Cafersoy, “4 Gün Savaş1” ve Bölgesel Dengeler, https://www.dw.com/tr/4-gün-savaş-ve-bölgeseldengeler/a-19168839, 06.04.2016, (Erişim Tarihi: 09.12.2020).

7 Aprel döyüşləri - böyük zəfərin başlanğıc1, https://mod.gov.az/az/pre/21662.html, 17.02.2018, (Erişim Tarihi: $09.12 .2020)$. 
ve Türkiye'nin Azerbaycan'a verdiği destek Ermenistan'ı hayal kırıklığına uğratmıştır. ABD ile AB'nin tutumu tarafları müzakere masasına davet eden diplomatik söylemlerle sınırlı kalmıştır. Fransa her zaman olduğu gibi yine Ermeni yanlısı bir tutum sergilemiştir. AKPM Başkanı Pedro Agramunt, BM Güvenlik Konseyi kararlarına uygun olarak Ermenistan'ın elinde bulunan Azerbaycan topraklarını terk etmesi ve anlaşmaya varılması gerektiğini belirtmiştir. ${ }^{8}$ Savaş sırasında Azerbaycan halkının orduya verdiği yoğun destek Karabağ'ın savaş yoluyla geri alınacağına dair umutların ne kadar diri olduğunu gösterirken, halkın motivasyon ve moralini bir hayli yükseltmiştir. Bu motivasyon 2020'de yaşanacak Tovuz muharebesi ve 44 Gün Savaşı sırasında yankı bulacak kadar yüksekti.

\section{TOVUZ SAVAȘI (12-18 Temmuz 2020)}

Ermenistan ordusu 12 Temmuz 2020 tarihinde Azerbaycan-Ermenistan sinır hattında yer alan Tovuz bölgesine saldırmıştır. Saldırılar sadece 12 Temmuz'la sınırlı kalmamış, ilerleyen günlerde de aralıklı olarak devam etmiştir. Ermenistan daha önce de defalarca bu bölgede Azerbaycan'ın sivil ve askeri yerleşim yerlerine taciz ateşi açarak ve saldırıda bulunarak ateşkes rejimini ihlal etmiştir. Fakat 12 Temmuz'da yapılan bu saldırı 4 Gün Savaşı'ndan sonra bölgede yaşanan en büyük çatışma olarak kayıtlara geçmiştir. Öncelikle şunu belirtmek gerekir ki burası, son derece önemli projelerin, Türkiye ve Azerbaycan'ın ortaklaşa gerçekleştirdiği Bakü-TiflisKars demir yolunun, Bakü-Tiflis-Ceyhan petrol boru hattının ve TANAP'ın başlangıcı olan Güney Kafkasya doğal gaz boru hattının geçtiği bir bölgedir. ${ }^{9}$ Peki, Ermenistan'ın Karabağ'la ilgisi olmayan bu bölgeye saldırısının arkasında duran sebepler nelerdir? Ermenistan, bu savaşı başlatarak müttefiklerinin desteğini almayı ve bu sayede Azerbaycan'ın ekonomik gücünü yıpratmayı hedeflemiştir. Ayrıca, Türkiye'yi savaşın içine çekerek son dönemde daha da gelişen Türkiye-Azerbaycan ilişkilerini sekteye uğratmak Ermenistan'ın bir başka hedefidir diyebiliriz. Tovuz saldırısının nedenini sadece enerji hatlarına bağlamak doğru değildir. Çünkü Ermeniler bu bölgeye Kuzey Karabağ adını vererek öteden beri hak iddia ederken, gelecekte Gence ve Mingeçevir hattını da almayı planlamışlardır. Samvel Karapetyan isimli bir Ermeni araştırmacı 2018 yılında, Rusya'da “Kuzey Artsah” (Karabağ) adlı bir kitap yayınlayarak Gazah ve Tovuz bölgelerinde gerçekleştirilen saha çalışmalarından, Ermeni kültürü ve tarihinden, mimari eserler ve kiliselerinden bahsetmiştir. Kapağında Tovuz-Gazah bölgelerini kapsayan, “Kuzey Artsah” adı verilen bir haritayı da içeren bu kitap Rusya’da, yaklaşık 200 üniversite ve kütüphaneye gönderilmiştir. ${ }^{10}$ Bilindiği gibi son derece fakir ve dışa bağımlı bir ülke olan Ermenistan, ekonomik sorunların üstesinden gelememektedir. Diğer yandan pandemi nedeniyle

8 Bkz: Nazim Cafersoy, “4 Gün Savaşı” ve Bölgesel Dengeler, https://www.dw.com/tr/4-gün-savaş-ve-bölgeseldengeler/a-19168839, 06.04.2016, (Erişim Tarihi: 09.12.2020).

9 Ruslan Rehimov, Ermenistan, Türkiye ve Azerbaycan'ın ortak projelerinin bulunduğu bölgede saldırı düzenliyor, https://www.aa.com.tr/tr/dunya/ermenistan-turkiye-ve-azerbaycanin-ortak-projelerinin-bulundugu-bolgedesaldiri-duzenliyor/1913508, 17.07.2020, (Erişim Tarihi: 10.12.2020).

10 Ramin Sadıgov, Ermenistan'ın son saldırısı nasil okunmalı?, https://fikirturu.com/jeo-strateji/ermenistanin-sonsaldirisi-nasil-okunmali/, 22.07.2020, (Erişim Tarihi: 10.12.2020). 
ülke adeta felç olmuş durumdadır. Virüsle mücadelede başarılı olamayan Ermenistan, Fransa ve Rusya'dan yardım talebinde bulunmuştur. Böyle bir ortamda, Başbakan Nikol Paşinyan, iç sorunlarla baş edememenin faturasının ağır olacağını bilerek hedef şaşırtmayı amaçlamış olabilir. ${ }^{11}$

Azerbaycan Cumhurbaşkanı İlham Aliyev yaptığı açıklamada, sivil yerleşim yerlerine saldırıda bulunan Ermenistan'ın faşist bir devlet olduğunun altını çizmiş, Ermeni güçlerinin bir santim dahi ilerleyemediğini ve bunu hiçbir zaman başaramayacağını belirtmiştir. Ayrıca Aliyev, Azerbaycan'ın istediği takdirde Ermenistan'ın o bölgesindeki topraklarının büyük bir kısmını ele geçirebileceğini ancak böyle bir hedefleri olmadığını da sözlerine eklemiştir. ${ }^{12}$ Tovuz saldırısı sırasında Türkiye Azerbaycan'a her türlü destekte bulunmaya hazır olduğunu belirtmiş, en üst düzey devlet makamları bu saldırılarla ilgili en sert tepkilerini dile getirmişlerdir. Cumhurbaşkanı Recep Tayip Erdoğan, yapılan saldırıları şiddetlere kınadıklarını ve bu durumun sıradan bir sınır ihlali çatışması değil, aksine doğrudan Azerbaycan'a karşı yapılan ve Ermenistan'ın çapını aşan bir saldırı olduğunu dile getirmiştir. ${ }^{13}$ Türkiye Cumhuriyeti Dışişleri Bakanlığı tarafından yapılan açıklamada, uluslararası kamuoyunun dikkatini başka bir yöne çevirerek, ihtilafa yeni bir boyut kazandırmak istediği, ancak bu hareketin sonuçsuz kalacağı ifade edilmiştir. Bakanlık, Ermenistan'ın boyunu aşan arzuları uğruna maceraperestliğe giriştiğini, bölgede istikrar ve barışın önüne geçtiğini vurgularken, Türkiye'nin her zaman kendi topraklarını koruyan Azerbaycan'ın yanında olacağını belirtmiştir. ${ }^{14}$ Milli Savunma Bakanı Hulusi Akar, “Azerbaycan bizim canımızdır. Biz Türkiye olarak daima can kardeşimiz Azerbaycan'ın yanında olmaya devam edeceğiz" şeklinde bir açıklamada bulunmuştur. Akar, Ermenistan'ın Karabağ' 1 haksız ve hukuka uygun olmayan biçimde işgal ettiğini ve Tovuz bölgesine haddini aşan saldırılar gerçekleştirdiğini belirterek, Azerbaycan'ın acısını derinden hissettiklerini, bu saldırıyı en ağır şekilde kınadıklarını ve her zaman Azerbaycan'ın yanında olduklarını dile getirmiştir. $^{15}$

Türkiye'nin Azerbaycan'a olan desteği son derece açık şekilde ifade edilmiş olup arkasında reel askeri ve siyasi güç barındırmıştır. Türkiye-Azerbaycan ilişkilerinin askeri boyutunun her geçen gün güçlenmesi yapılan açıklamalardaki özgüven ruhunu daha da kuvvetlendirmiştir.

11 Ramin Sadıgov, Ermenistan'ın son saldırısı nasıl okunmalı?, https:/fikirturu.com/jeo-strateji/ermenistanin-sonsaldirisi-nasil-okunmali/, 22.07.2020, (Erişim Tarihi: 10.12.2020).

12 Azerbaycan Cumhurbaşkanı Aliyev'den sivil yerleşimleri hedef alan Ermenistan'a tepki: Faşist devlet, https:// www.haberler.com/azerbaycan-cumhurbaskani-aliyev-ermenistan-fasist-13423804-haberi/, 15.07.2020, (Erişim Tarihi: 13.03.2021).

13 Cumhurbaşkanı Erdoğan: Bu saldırı Ermenistan'ın çapını aşan bir hadisedir, https://qha.com.tr/haberler/guncel/ cumhurbaskani-erdogan-bu-saldiri-ermenistan-in-capini-asan-bir-hadisedir/224116/, 14.07.2020, (Erișim Tarihi: 13.03.2021).

14 No: 149, 12 Temmuz 2020, Azerbaycan’a Yönelik Ermeni Saldırısı Hk., https://web.archive.org/ web/20200712222134/http://www.mfa.gov.tr/no_-149_-azerbaycan-a-yonelik-ermeni-saldirisi-hk.tr.mfa, (Erişim Tarihi: 10.02.2021).

15 Milli Savunma Bakanı Hulusi Akar'dan Fransa'ya sert tepki: Herkesin efelik yapacağı bir ülke olmadığımızı görsünler, https://www.takvim.com.tr/guncel/2020/07/17/milli-savunma-bakani-hulusi-akardan-fransaya-serttepki-herkesin-efelik-yapacagi-bir-ulke-olmadigimizi-gorsunler, 17.07.2020, (Erişim Tarihi: 10.02.2021). 


\section{BÜYÜK TAARRUZ: 44 GÜN DEVAM EDEN İKİNCİ KARABAĞ SAVAŞI}

Tovuz'da yaşanan çatışmaların üzerinden çok geçmeden Azerbaycan istihbaratına Ermenistan'ın Karabağ'a bir saldırı planlandığına dair bilgiler dâhil olmuştur. Azerbaycan yönetimi bu konudaki bilgileri kamuoyuyla paylaşırken saldırıyı def edecek her türlü hazırlığa sahip olduğunu vurgulamıştır. Bu kapsamda, savaş öncesinde yönetim makamlarında gerçekleştirilen yeni atama ve görev değişiklikleri dikkat çeken bir diğer husustur. Bu gelişme son derecede önemli olup, savaş öncesi alınan önlemlerin bir parçası olarak değerlendirilebilir. Ermenistan'ın saldırı planları konusundaki bilgiler, Eylül ayının ortalarına gelindiğinde daha da netlik kazanmıştır.

Ermeni güçleri, 27 Eylül 2020 'de sabaha karşı saldırıya başlamıştır. Karşı saldırıya geçen Azerbaycan ordusu başarılı askeri harekât idaresi sayesinde önemli mevziileri kontrolü altına alarak, ilerlemeye devam etmiştir. Çatı̧̧manın seyrinin bu şekilde olacağını önceden tahmin edemeyen Ermenistan ordusu aldığı darbelerle neye uğradığını şaşırmıştır. İlk saldırılarda 12 hava savunma sisteminin imha edildiği Ermenistan ordusu, Azerbaycan güçlerinin silahlı insansız hava araçları ve helikopterlerle yaptığı başarılı saldırılar karşısında büyük zayiat vererek, önemli mevziileri terk etmek zorunda kalmıştır. Azerbaycan ordusu Füzuli, Cebrayıl, Terter ve Ağdam bölgelerindeki köyleri arka arkaya işgalden kurtarırken bağlantı ve ikmal yollarını da kontrolü altına almıştır. Bir başka dikkat çeken husus; Azerbaycan ordusunun Ermeni sivilleri konusunda son derece ihtiyatlı bir tutum sergilemesine rağmen, Ermeni silahlı birliklerinin Azerbaycan'a ait sivil yerleşim birimlerini hedef almalarıdır. ${ }^{16}$ Arka arkaya ciddi yenilgiler yaşayan Ermenistan, uluslararası kuruluşlar ve büyük devletlerin kapısını adeta aşındırarak duruma müdahil olmalarını istemiştir. Çatışan taraflara sunulan ateşkes önerilerine karşılık Aliyev, sadece Ermeni ordusunun Azerbaycan topraklarını tamamen terk etmesi ve Paşinyan yönetiminin uluslararası kamuoyu önünde Azerbaycan'dan özür dilemesi durumunda, Azerbaycan hükümetinin müzakere masasına oturabileceğini vurgulamıştır. ${ }^{17}$

Savaş sırasında Azerbaycan ile Ermenistan orduları arasındaki farklar belirgin bir şekilde ortaya çıkmıştır. Sivilleri vurmama, askeri hedefleri nokta atışıla imha etme, olabildiğince az zayiatla ilerleme Azerbaycan ordusunun başarı kazanmasını sağlayan taktik ilkelerdi. Ermenistan savaş sahasından askeri araçlarını taşımaya dahi firsat bulamadan bırakarak kaçmış, sivillere saldırarak Azerbaycan'ı yeni bir provokasyon içine çekmek istemiştir. Fakat Azerbaycan ordusu başından beri belirlediği ilkeler doğrultusunda hareket ederek sağduyulu ve istikrarlı

16 Ali Asker, İşgalin Kırılma Noktası veya Yalancı Ateşkesin Sonu: Eylül 2020 Azerbaycan-Ermenistan Savaşını Geniş Tablodan Okumak, https://www.sde.org.tr/degerlendirme/isgalin-kirilma-noktasi-veya-yalanci-ateskesinsonu-eylul-2020-azerbaycan-ermenistan-savasini-genis-tablodan-okumak-analizi-18517, 30.09.2020, (Erişim Tarihi: 09.12.2020).

17 Ali Asker, Doç. Dr. Asker: Kremlin'den Umduğunu Bulamayan Paşinyan Çaresiz Bir Şekilde Yenilgiyi Seyrediyor, https://qha.com.tr/haberler/doc-dr-asker-kremlin-den-umdugunu-bulamayan-pasinyan-caresiz-bir-sekildeyenilgiyi-seyrediyor/255810/,08.10.2020, (Erişim Tarihi: 09.12.2020). 
tavrını korumuştur. ${ }^{18}$ Savaş sırasında Rusya, tarafları bir araya getirerek ateşkes imzalamaları konusunda baskı ve telkinlerde bulunmuştur. Sahada kazanımları olan Azerbaycan için bu tür ateşkes önerileri aslında bir masa tuzağıydı. ${ }^{19} 27$ Eylül'den 9 Kasım tarihine kadar geçen süre zarfında Azerbaycan ordusu iki yüz doksandan fazla yerleşim yerini işgalden kurtarmıştır. Son olarak Şuşa’nın işgalden kurtarılması Ermenistan yönetimini mağlubiyeti kabullenmeye mecbur bırakmıştır. Dağlık Karabağ'ın sözde lideri Arayik Harutyunyan'ın 'Çatışmalar aynı hızda devam etseydi birkaç gün içinde Karabă̆’ın tamamını kaybedecektik. İmzalanan anlaşma zorunluydu ve değiştirilemez" şeklindeki itirafı Azerbaycan ordusunun cephedeki galibiyetini ortaya koymaktadır. ${ }^{20}$

II. Karabağ Savaşı stratejik ve taktik başarıları, ayrıca teknolojik vasıtaların kullanımı konusunda askeri uzmanların dikkatlerini üzerine çeken son derece ilginç bir savaştır. Bu savaşla ilgili yakın gelecekte harp uzmanlarının ilginç yorumlarına tanıklık edebileceğiz.

\section{SAVAŞA DAIR TARAFLARIN TUTUMLARI}

\subsection{Sorunun Asıl Aktörleri}

Yapay bir sorun olarak üretilen "Karabağ sorunu” Azerbaycan açısından kendi topraklarına yönelik bir işgal meselesidir. Azerbaycan için toprak bütünlüğü büyük öneme sahiptir. Dağlık Karabağ Azerbaycan'ın ayrılmaz bir parçasını teşkil etmektedir ve bu yüzden Azerbaycan'ın esas gayesi toprak bütünlüğünü yeniden tesis etmektir. Azerbaycan ayrıca, ekonomik güç bakımından da Ermenistan'a oranla açık ara öndedir; artan gelirler sayesinde savunma sanayiye ayrılan bütçe sürekli artış göstermektedir. Büyüyen ekonomi ve artan petrol gelirleri ordunun güçlendirilmesi açısından önemli avantaj sağlamaktadır. Uzun süredir Azerbaycan'ın kendi topraklarını askeri güç kullanarak kurtarabileceği düşüncesi uzmanlar tarafından dile getirilmekteydi. ${ }^{21} 27$ Eylül 2020'de başlayan askeri harekât bu yöndeki tespitleri kesin şekilde doğrulamıştır. Ermenistan'ın arkasına aldığı diplomatik destek sayesinde yıllarca süren işgal siyaseti kesintisiz bir şekilde devam etmiştir. Ermenistan her zaman olduğu gibi bu savaşa da büyük güçleri dâhil etmek ve arkasına diplomatik destek alarak sorunu "halletmek" istemiş, ateşkes ihlallerinde bulunarak KGAÖ’yü bölgeye çekmek ve Azerbaycan yönetimini yalnız bırakmak için uğraşmış, fakat herhangi bir sonuç alamamıştır. Tarafları ateşkese ve anlaşma

18 Ali Asker, Afgan Bakhshaliyev, "Rusya'nın Kafkasya Politikasında Karabağ Faktörü”, I. Uluslararası Sovyet Sonrası Türkiye-Rusya İlişkileri Sempozyumu, 15-16 Ekim 2020, Ege Üniversitesi Türk Dünyası Araştırmaları Enstitüsü, İzmir 2020 (ss. 49-59), s. 55-56.

19 Bkz: Ali Asker, 10 Ekim 2020 Tarihli Ateşkes veya "Masa Tuzağı”, https://kafkassam.com/10-ekim2020-tarihli-ateskes-veya-masa-tuzagi.html?fbclid=IwAR0rplYfDcEPE8Hgt1 fs148Vg3HSOwY2GiQ7BA0FQ11hn0BfK1UEW6Zy3I, 10.10.2020, (Erişim Tarihi: 09.12.2020).

20 Mehmet Çağatay Güler, Karabağ’ın Özgürleştirilmesi ve Sahadaki Yeni Denklem, https://www.setav.org/ perspektif-karabagin-ozgurlestirilmesi-ve-sahadaki-yeni-denklem/, 11.10.2020, (Erişim Tarihi: 16.12.2020).

21 Bu konudaki değerlendirmeler için bkz: İdil Tunçer Kılavuz, "Dağlık Karabağ Müzakerelerinin Geleceği”, Avrasya Etütleri, Sayı: 52 (2017) (ss. 51-78), s. 61-62. 
yoluna çağıran KGAÖ, Azerbaycan'ı engelleyecek herhangi bir harekette bulunmamıştır. ${ }^{22}$ Bunun yanı sıra, Ermenistan'ın Azerbaycan'a karşı yürüttüğü psikolojik savaş stratejisi de iflas etmiştir. Yıllardır Rusya'nın arkasına saklanan Ermenistan, Rusya tarafsız kalınca çaresiz duruma düşmüştür. Bu savaş Ermenistan'ın asla terk etmek istemediği işgalci politikasının sonunu getirmiş, onu, yeni oluşan diplomatik ve askeri durumu kabullenmek zorunda bırakmıştır. ${ }^{23}$

\subsection{Bölgesel Aktörler ve Minsk Üçlüsü Eş Başkanları}

Dağlık Karabağ sorunuyla ilgili süreçte yer alan bölgesel aktörler Rusya, Türkiye ve İran'dır. Bunun dışında Minsk Gurubu Eş başkanları olarak ABD ve Fransa'nın da savaş konusunda nasıl bir politika izlediklerini irdelemek çok önemlidir.

Türkiye'nin bu konudaki tutumu her zaman açık olmuştur. Ankara yönetimi uluslararası hukuk kuralları ve BM Güvenlik Konseyi'nin ilgili kararlarına atıfta bulunan Azerbaycan'ın haklı davasını her zaman desteklemiş, işgal sona ermeden Ermenistan yönetimi ile görüşmeyeceğini birçok kez belirtmiştir. Azerbaycan-Ermenistan çatışmasında Ermeni yanlısı koalisyonları dengeleyebilecek tek aktör Türkiye'dir. Özellikle son dönemde Türkiye'nin askeri faktörleri daha çok kullanmaya başladığı görülmüştür. Bu yaklaşımın masada somut avantajlar elde etme gayesiyle tercih edildiğini söyleyebiliriz. Türkiye'nin stratejik desteği sayesinde Azerbaycan, belirgin biçimde harekât kabiliyetini arttırarak, sahadaki kazanımlarını artırmıştır. ${ }^{24}$ Türkiye tarafı Azerbaycan'a olan destek mesajlarını en üst düzeyde dile getirmiş ve savaşın sonuna kadar kesintisiz şekilde sürdürmüştür. Cumhurbaşkanı Recep Tayyip Erdoğan yaptığı bir açıklamada, Dağlık Karabağ sorununda Türkiye'nin her daim Azerbaycan'ı desteklediğini belirterek, işgalle başlayan soruna artık son verilmesi gerektiğini vurgulamış ve işgale uğrayan toprakların Azerbaycan'a ait olduğunu, hesap verme zamanı geldiğini ve Azerbaycan'ın bu saatten sonra kendi göbeğini kendisinin keseceğini söylemiştir. Milli Savunma Bakanı Hulusi Akar, topraklarını savunmasında her zaman Azerbaycan'ın yanında olduklarını ifade etmiştir. ${ }^{25}$ Dışişleri Bakanı Mevlüt Çavuşoğlu bu sorunu kökünden çözmeyi arzuladıklarını ve Türk diplomasisi olarak dünyanın her tarafında kardeş ülke Azerbaycan'ın destekleneceğini belirtmiştir. Çavuşoğlu, bilhassa Azerbaycan'ın büyükelçiliğinin bulunmadığı yerlerde Türk

22 Mehmet Çağatay Güler, 5 Soru: Dağlık Karabağ Çatışması: Azerbaycan-Ermenistan İlişkilerinde Bir Kırılma m1, https:/www.setav.org/5-soru-daglik-karabag-catismasi-azerbaycan-ermenistan-iliskilerinde-bir-kirilma-mi/, 29.09.2020, (Erişim Tarihi: 09.12.2020).

23 Ali Asker, İşgalin Kırılma Noktası veya Yalancı Ateşkesin Sonu: Eylül 2020 Azerbaycan-Ermenistan Savaşını Geniş Tablodan Okumak, https://www.sde.org.tr/degerlendirme/isgalin-kirilma-noktasi-veya-yalanci-ateskesinsonu-eylul-2020-azerbaycan-ermenistan-savasini-genis-tablodan-okumak-analizi-18517, 30.09.2020, (Erişim Tarihi: 09.12.2020).

24 Mehmet Çağatay Güler, 5 Soru: Dağlık Karabağ Çatışması: Azerbaycan-Ermenistan İlişkilerinde Bir Kırılma m1, https:/www.setav.org/5-soru-daglik-karabag-catismasi-azerbaycan-ermenistan-iliskilerinde-bir-kirilma-mi/, 29.09.2020, (Erişim Tarihi: 09.12.2020).

25 Dağlık Karabağ: Ermenistan Türkiye'yi çatışmalarda Azerbaycan'a askeri destek vermekle suçladı, https:// www.bbc.com/turkce/haberler-dunya-54315251, 28.09.2020, (Erişim Tarihi: 12.03.2021). 
temsilciliklerin Azerbaycan için de çalışacağını söylemiştir. ${ }^{26}$ TBMM başkanı Mustafa Şentop resmi temaslarda bulunmak için geldiği Azerbaycan Milli Meclisi’nde bir konuşma yaparak, Karabağ sorununa yıllardır bir çözüm getiremeyen AGİT Minsk Grubu'nun beyin ölümünün gerçekleştiğini, bugüne kadar olduğu gibi bugünden sonra da Azerbaycan'ın haklı davasında ve vatan savunmasında yanlarında olacaklarını söylemiştir. ${ }^{27}$

Yıllar boyu Dağlık Karabağ sorununda Ermenistan'ın yanında yer alan Rusya Federasyonu İkinci Karabağ Savaşı'nda pasif bir siyaset izlemiştir. Bu durum Ermenistan açısında tam bir hezimet olmuştur. Aslında Rusya, Paşinyan yönetimi ile siyasi sorunlar yaşamış ve Karabağ sorunu üzerinden Ermenistan'1 yıpratmaya çalışmıştır. ${ }^{28}$ Rusya'nın bu savaşta sessiz kalması sadece Paşinyan'ı cezalandırmak isteğinden ileri gelmemiştir. Türkiye'nin bölgedeki artan gücü, kararlı tutumu, Rusya'nın açık askeri müdahalesi durumunda sürecin kontrolden çıkacağı ve Rusya'yı memnun etmeyen sonuçlar doğurabileceği ihtimali bu pasif tutumu etkileyen olgulardandır. 31 Ekim 2020 tarihinde Paşinyan, Rusya Devlet Başkanı Putin’e yazdığı mektupta Ortadoğu'dan gelen yabancı teröristlerin Azerbaycan safında savaşa katıldıklarını ve çatışmaların Ermenistan sınırına yaklaştığını vurgulamıştır. Eski Cumhurbaşkanı TerPetrosyan Paşinyan'ın mektup olayını şu şekilde yorumlamıştır: "Nikol, Vladimir Putin'e rica içerikli mektup gönderdi. Putin ona Dışişleri Bakanlı̆̆l aracılı̆̆lyla cevap verdi. Ne dediğini anlamadınız mı? Ĕger anlamadıysanız bize yazıklar olsun! Tam samimiyet ve nezaketle şunları söyledi: Ermenistan'ın tam güvenliğini sağlamaya mecbur ve hazırım, ama anlayın artık, sizin yerinize Karabağ sorununu çözemem. ” Paşinyan yönetimi savaş boyunca Rusya’yı olayların içine çekmek, yine Rusya'nın eliyle KGAÖ’yü “yükümlülüklerini yerine getirmeye” zorlamak için her türlü yola başvurmuşsa da beklentisi gerçekleşmemiştir. Yenilgiyle karşı karşıya kalan Ermenistan, savaşı uzatarak bir şekilde Rusya'nın desteğini almayı, onu ateşkes veya barış sürecinde söz sahibi yaparak asgari kayıpla bu durumundan çıkmayı hedeflemiştir. ${ }^{29}$

Bölgesel aktörler arasında İran’ın siyaseti birçok yönüyle dikkat çekmektedir. Bu siyasete çelişkili görünüm veren önemli hususların vurgulayabiliriz. Tanınmış Ortadoğu ve İran uzmanı Arif Keskin'e göre İran'ın Karabağ konusunda tutarsızlık gibi görünen eylem ve tutumlarının arkasında bütüncül bir yaklaşım ve beş yüzlü bir siyaset yatmaktadır. Son derece isabetli bir tanımlamada bulunan yazar, bu beş yüzlü siyaset olgusunu şöyle açıklamaktadır:

1) “Karabağ, Azerbaycan toprağıdır” söylemini dile getirmesine rağmen İran Karabağ ve çevresindeki işgal edilmiş yedi rayonu birbirinden ayrı düşünse de Karabağ'ın ayrı bir

26 Çavuşoğlu'ndan Karabağ açıklaması: Artık bu meseleyi kökünden çözmek istiyoruz, https://www.haberturk. com/cavusoglu-ndan-karabag-aciklamasi-artik-bu-meseleyi-kokunden-cozmek-istiyoruz-2818652, 29.09.2020, (Erişim Tarihi: 12.03.2021).

27 Son dakika haberi: TBMM Başkanı Mustafa Şentop’tan flaş açıklamalar, https://www.hurriyet.com.tr/gundem/ son-dakika-haberi-tbmm-baskani-mustafa-sentoptan-flas-aciklamalar-41640812, 20.10.2020, (Erişim Tarihi: 12.03.2021).

28 Hacı Mehmet Boyraz, Oğuz Güngörmez, Karabağ Zaferinin Anatomisi, https://www.setav.org/karabag-zaferininanatomisi/, 10.12.2020, (Erişim Tarihi: 16.12. 2020).

29 Ali Asker, Başarısız Hamle: Paşinyan'ın Mektubu, https://kafkassam.com/basarisiz-hamle-pasinyanin-mektubu. html, , 01.11.2020, (Erişim Tarihi: 09.12.2020). 
statüde değerlendirilmesi gerektiğini düşünmektedir.

2) İran, Karabağ’daki Şii/Müslümanlara zulüm uygulandığına dair İran'daki din adamlarının açıklamaları "ülke içinde ve dışındaki dindar kesime yönelik, ortaya çıkan tutarsızlığı kapatmak, muhtemel hayal kırklıklarını tamir, tadil ve yumuşatmaya dönük kamu diplomasisi girişmeleri olarak yorumlanabilir."

3) Karabağ meselesi İran'daki Türk milliyetçiliğini mobilize edebilecek kadar hassas bir konudur. Çatışmanın büyümesi halinde Rusya, Türkiye, Fransa, ABD ve muhtemel İsrail gibi ülkelerin askeri anlamda bölgeye girme ihtimali söz konusudur. Bu yüzden İran'ın resmî açıklamalarının büyük bölümünü ateşkes, arabuluculuk gibi sözler teşkil ediyor.

4) İran'ın bölgesel politikası; Ermenistan'ın Azerbaycan'la gergin ilişkisinin devam ettirilmesi ve bu sayede Azerbaycan'ın büyümesini engellemeye yöneliktir. Bu yüzden, güçlü bir Azerbaycan'a tahammül etmeyen İran yönetimi Ermenistan'la iyi ilişkiler kurarak ona yardımda bulunmuştur.

5) İran'ın Karabağ politikası Ari/Pers milliyetçiliği ekseninde gelişmiştir. Bu zihniyet hala İran'ın bir parçası olarak gördüğü Azerbaycan'ı İran Uygarlık Havzası içine konumlandırmaktadır. Bu yüzden İran, zayıf ve yenilmiş bir Azerbaycan' dan yanadır. ${ }^{30}$

Türkiye'nin bölgesel ve küresel anlamda etki alanlarının artarak devam edeceği endişesi de İran'1 büyük ölçüde tedirgin etmektedir. Karabağ sorununda İran'ın, Azerbaycan milleti, uluslararası toplumu ve İran Türklerini hedef alan propaganda hareketi, güven sorunu, söylemeylem çelişkisi gibi sebeplerle başarısız olmuştur. ${ }^{31}$ İran, Karabağ'ın Azerbaycan toprağ olduğunu söylerken diğer taraftan Ermenistan'a silah yardımında bulundukları görüntüler ortaya çıkması ile çelişkili bir görüntü sergilemiş ve İran polisinin, Azerbaycan'a destek yürüyüşü yapan göstericilere sert müdahalede bulunması İran'ın asıl düşüncesini gözler önüne sermiştir. ${ }^{32}$ Yukarıda bahsi geçen beş yüzlü politikanın etkisiyle, özellikle savaşın ilerleyen safhasında, dahası Azerbaycan'ın açık şekilde üstünlük sağladığı zaman İran siyasi seçkinleri, Karabă̆ konusunda adeta ikiye ayrılmışlardır; bir kısmı Ermenistan'ı desteklemeye devam ederken diğer kısmı böyle bir politikanın İran'ın onurunu zedeleyerek, pragmatik olmayan bir dış politika kulvarına iteceği uyarısında bulunmuştur. Sürekli açık veya dolaylı yoldan Ermenistan'ın işgal politikasını destekleyen İran'ın II. Karabağ Savaşı boyunca samimiyetsiz bir politika izlediği bilinen bir gerçekliktir.

II. Karabağ Savaşı'nın zamanlaması birçok açıdan Azerbaycan'ın lehine olacak durumların ortaya çıkmasıyla dikkat çekmektedir: Azerbaycan ve Türkiye arasındaki askeri iş birliği konusunda somut adımların atılması, askeri tatbikat sonrası uçaklar dâhil birçok savaş aracının

30 Arif Keskin, İran'ın Karabağ Siyasetinin 5 Yüzü, https://fikirturu.com/jeo-strateji/iranin-karabag-siyasetinin5-yuzu/, 12.10.2020, (Erişim Tarihi: 16.02. 2021).

31 Çağatay Balcı, İran'ın Karabağ propagandası neden başarısız oldu, https://www.aa.com.tr/tr/analiz/iran-inkarabag-propagandasi-neden-basarisiz-oldu/2027725, 02.11.2020, (Erişim Tarihi: 14.12.2020).

32 Turgut Alp Boyraz, Mustafa Melih Ahıshalı, İran yönetiminin Dağlık Karabağ konusundaki tutumu ne, https:// www.aa.com.tr/tr/a.zerbaycan-cephe-hatti/iran-yonetiminin-daglik-karabag-konusundaki-tutumu-ne/1998888, 07.10.2020, (Erişim Tarihi: 08.01.2021). 
Azerbaycan sınırları içinde kalması, dünyayı saran Covid-19'a karşı aktif mücadelenin beklenen sonuçları vermemesi ve küresel risk düzeyinin yüksek olması, ABD'de başkanlık seçimlerinin hassas bir evreye girmesi, harekâtın kış gelmeden ve havalar soğumadan başlatılması vd. Muhtemel bir Azerbaycan-Ermenistan savaşında Ermenistan'a destek vereceği sanılan devletler arasında ABD ve Fransa'nın ilk sıralarda yer alacağı düşünülmüştür. Fakat Amerika çatışma süresince pasif bir tutum sergileyerek Azerbaycan'ın zafere ulaşmasının önünde herhangi bir engel teşkil etmemiştir. Bunun başlıca sebebi, 2020 yılında ABD başkanlık seçimindeki kıyasıya rekabettir. Amerika'daki başkanlık yarışı sebebiyle devlet iç gündemine ağırlık vermiş ve Karabağ' daki olayları uzaktan seyretmekle yetinerek, Ermenistan'ın çabalarını boşa çıkarmıştır. ${ }^{33}$

Ermenistan'a en fazla destek veren ülke Fransa olmuştur. Cumhurbaşkanı Macron işgalci Ermenistan’ı desteklemiş ve özellikle Türkiye'ye karşı suçlayıcı açıklamalarda bulunmuştur. Fakat bu açıklamalar, başka devletleri olayların içine çekmeye çalışan ve kışkırtıcı siyaset izleyen Ermenistan lehine somut bir kazanım sağlamamıştır. Fransa’nın uluslararası medyada, ateşkesler esnasında hava yolu aracılığıyla yüksek teknolojili silahları Ermenistan'a gönderdiği, böylece çatışmalara etkin olarak destek sağladığı ortaya çıkmıştır. ${ }^{34}$ Fransa'nın Ermeni yanlısı politika izlemesi bu ülkedeki güçlü Ermeni lobisinin baskılarından kaynaklanmaktadır. Bu baskı sayesinde Fransa zaten senelerdir Türkiye'ye karşı sözde soykırım iddiasıyla ilgili kararlar alırken, Karabağ Savaşı'nda Azerbaycan karşıtı bir tutum sergilemiştir. AGİT Minsk Grubu'nun eş başkanı olarak Fransa, ön plana çıkmaya, kendisine siyasi bakımdan alan açmaya çalışmıştır. Karabağ sorununda Fransa'nın böyle bir yol tercih etmesinin bir diğer nedeni, Türkiye'nin masadaki ve sahadaki varlığından rahatsız olmasından kaynaklanmıştır. ${ }^{35}$ Azerbaycan'ın sahadaki zaferlerini hazmedemeyen Fransa Senatosu, 25 Kasım 2020 tarihinde "Dağlık Karabağ Cumhuriyeti'ni” tanıyan bir karar kabul etmiştir. Sembolik değere sahip bu karar, 1 "hayır" oyuna karşı 305 "evet” oyuyla kabul edilmiştir. Oylamada 30 senatör “çekimser" oy kullanmıştır. Türkiye bu karara sert tepki vermiş ve Türkiye Büyük Millet Meclisi’nde grubu bulunan siyasi partiler (HDP hariç) "uluslararası hukuka, ahlaka ve hakkaniyete aykırı bir şekilde kabul ettiği” Fransa Senatosu'nun bu kararını “en güçlü şekilde” kınayarak “yok hükmünde" saymışlardır. ${ }^{36}$ Kararla ilgili Türkiye Dışişleri Bakanlığı tarafından yayımlanmış 26.11.2020 tarihli açıklamada şöyle denilmektedir: “Esasen, Azerbaycan'ın sahada aldı̆̆ sonuç, BM kararlarına yansımış, Fransa'nın da eş başkanı olduğu Minsk sürecinde kayıt altına alınmış ancak hayata geçirilememiş haklarının somutlaştırılmasıdır. Zira ilgili BM kararları Ermenilerin işgal ettiği Azerbaycan topraklarından derhal ve şartsız çekilmelerini amirdir.

33 Hacı Mehmet Boyraz, Oğuz Güngörmez, Karabağ Zaferinin Anatomisi, https://www.setav.org/karabag-zaferininanatomisi/, 10.12.2020, (Erişim Tarihi: 16.12. 2020).

34 Hacı Mehmet Boyraz, Avrupa'nın Dağlık Karabağ Tutumu, https://www.setav.org/avrupanin-daglik-karabagtutumu/, 04.12.2020, (Erişim Tarihi: 09.12.2020).

35 Hacı Mehmet Boyraz, Avrupa'nın Dağlık Karabağ Tutumu, https://www.setav.org/avrupanin-daglik-karabagtutumu/, 04.12.2020, (Erişim Tarihi: 09.12.2020).

36 TBMM'de 4 partiden Fransa Senatosu'nun skandal Dağlık Karabağ kararına kınama, https://www.haberler.com/ tbmm-de-4-partiden-fransa-senatosu-nun-skandal-13763928-haberi/, 27.11.2020, (Erişim Tarihi: 09.12.2020). 
Hal böyle iken, Fransa Senatosu'nun Azerbaycan'a işgalden kurtardığı kendi topraklarından çekilmesi çă̆rısında bulunması ciddiye alınamayacak kadar gülünç, tarafgir ve gerçeklerden kopuk bir anlayışın tezahürüdür. Hiçbir makul gerekçeyle izah edilemeyecek olan bu sağduyudan yoksun karar, Fransa'nın meselenin çözümüne gerçek anlamda katkı sağlama imkânını da sınırlamaktadır. Fransa Hükümeti'nin de kabul edilemez bulacă̆ı unsurlar içerdiği görülen kararın, yine son dönemde Fransa'da sıkça görülen Türkiye takıntısını yansıtması ise şaşırtıcı olmasa da düşündürücüdür. "37

Fransa'nın kararı Cumhurbaşkanı İlham Aliyev tarafından sert bir dille eleştirilmiştir. İlham Aliyev, bu karar üzerine yaptığı açıklamada çok istiyorlarsa Ermenilere Marsilya’yı vermelerini ve Ermenilerin orada devletlerini kurmalarını söylemiştir. ${ }^{38}$

Özetlemek gerekirse, bölgesel aktörler olarak Rusya ve İran doğrudan veya dolaylı olarak her zaman Ermenistan'ın yanında yer almıştır. Bu savaşta ise Rusya uzun süre suskunluğunu korurken İran'ın çelişkili siyaseti ne kendine ne Ermenistan'a fayda sağlamıştır. ABD ise başkanlık seçimleri nedeniyle bölgeye zaman ayırmamıştır. Fransa'nın verdiği destek sadece diplomatik nitelikli olduğu için Ermenistan'1n cephedeki yenilgisini engelleyememiştir.

\subsection{Uluslararası Örgütler}

Azerbaycan-Ermenistan çatışmasının sonlandırmak ve işgal sorununu çözmek konusunda ne yazık otuz sene boyunca herhangi bir ilerleme sağlanamamış, BM Güvenlik Konseyi’nin aldığı 822, 853, 874 ve 884 no'lu kararların ${ }^{39}$ uygulanması sürüncemede bırakılmıştır. Avrupa Birliği’nin sorunun çözümüne ilişkin girişimleri başarısız olduğu gibi yetkili ağızlardan çelişkili açıklamalar yapılmıştır. ${ }^{40}$ Minsk Grubu son derece pasif ve etkisiz olup yapıcı bir çözüm önerisi sunamamıştır. Zaten Ermenistan'a sürekli destek veren ABD, Rusya ve Fransa'nın eş başkanlığındaki bir Minsk Grubu'nun adil, hakka ve hakkaniyete dayalı bir karar alması imkânsızdı. Bu kapsamda düzenlenen çok sayıda müzakereden, tarafları memnun edecek herhangi bir sonuç alınamamıştır. ${ }^{41}$ NATO ise bu savaşa müdahil olmaktan uzak kalmıştır.

Genellikle, II. Karabağ Savaşı döneminde uluslararası örgütler olaya herhangi bir müdahalede bulunmamışlar. Ermeni örgütleri, AB’ye Ermenistan lehine karar aldırmaya çalışsalar da buna

37 No: 300, 26 Kasım 2020, Fransa Senatosu'nun Yukarı Karabă̆ İhtilafına İlişkin 25 Kasım 2020 Tarihinde Kabul Ettiği Karar Hk. http://www.mfa.gov.tr/no_-300_fransa-senatosu-nun-yukari-karabag-ihtilafina-iliskin-kararihk.tr.mfa, 26.11.2020, (Erişim Tarihi: 09.12.2020).

38 Aliyev'den Fransa'ya: Çok istiyorsanız Marsilya'yı Ermenilere verin, orada devlet kursunlar, https://tr.euronews. com/2020/12/01/aliyev-den-fransa-ya-cok-istiyorsan-z-marsilya-y-ermenilere-verin-orada-devlet-kursunlar, 01.12.2020, (Erişim Tarihi: 08.01.2021).

39 United Nations Security Council, Resolution 822, 30 April 1993; United Nations Security Council, Resolution 853, 29 July 1993; United Nations Security Council, Resolution 874, 14 October 1993; United Nations Security Council, Resolution 884, 12 November 1993. United Nations, "Security Council Resolutions -1993”, https://2001-2009. state.gov/p/eur/rls/or/13508.htm, (Erişim Tarihi:08.01.2021).

40 Bu konuda bkz: İlhan Aras, “Avrupa Birliği’nin Dağlık Karabağ Sorunundaki Rolü”, Avrasya Etüdleri, 51/2017-1 (ss. 95-122), s. $101 \mathrm{vd}$.

41 Bu konuda bkz: Nazim Caferov, Araz Aslanlı, "Karabağ Sorununda Ateşkes ve Rusya”, Ermeni Araştırmalarl, Say1: 53, 2016, (ss. 239-260). 
muvaffak olamamışlardır. AB Yüksek Temsilcisi Josep Borell bu çatışmada taraf olmayacaklarını açık şekilde vurgulamıştır. Avrupa Parlamentosu'nda yaptı̆̆ı konuşma sırasında birçok milletvekilinin Türkiye ve Azerbaycan'a karşı "harekete geçilmesini” istediğine değinen Borrel şunları ifade etmiştir: "Harekete geçmek' derken neyi kastediyorsunuz? Yapabileceğimizi yapıyoruz. AB Konseyi’nin müzakere edilmiş bir çözüm bulunması amacıyla destekleme kararı verdiği AGITT Minsk Grubu Eş Başkanlarını desteklemek için yapabileceğimiz ne varsa yaparız. İki tarafi çatışmayı durdurmaya zorlamak ve Türkiye'ye müdahil olmaya devam etmemesi için baskı uygulamak için yapabileceğimiz her şeyi yaparız. Ama 'harekete geçmek' derken kastettiğiniz askeri anlamda harekete geçmekse, bu söz konusu olamaz." ${ }^{2}$

Birleşmiş Milletler aldığı kararlarda işgalci devlete yönelik herhangi bir yaptırım mekanizması öngörmemiş, bilakis, tarafları barışa çağırmış, mağdur ve saldırgana aynı zaviyeden bakarak her iki tarafı suçlayıcı bir tavır takınmıştır. Ermenistan, savaşın sonuna kadar Azerbaycan'ın sivilleri vurduğuna dair yalan haberleri dolaşıma sokarak, BM'nin dikkatini çekmeye çalışmışsa da bu haberlere itibar edilmemiştir. BM'nin bu tavrı aslında Ermenistan yönetimine olan güvensizliğinin bir göstergesi olarak da değerlendirilebilir. BM bu gelişmelerden duyduğu endişeyi dile getirerek, çatışmalara son vermeleri için taraflara çağırıda bulunarak müzakereye geri dönmeleri gerektiğini vurgulamıştır. ${ }^{43}$ İlerleyen günlerde BM, Azerbaycan ve Ermenistan'a çatışmalara derhal son verme çağrısını yinelemiştir. BM Genel Sekreteri Antonio Guterres, sözcüsü Stephane Dujarric aracılığıyla yaptığı açıklamada, çatışmaların büyümesinden ve sivil nüfusun bulunduğu alanların hedef alınmasından duyduğu endişeyi dile getirmiştir. Genel Sekreter, taraflara "uluslararası insani hukuk çerçevesinde sivillerin ve sivil altyapının korunması yükümlülükleri” hatırlatarak uluslararası toplumun çağrılarına rağmen çatışmaların devam etmesini kınamış ve bu çatışmalara derhal son vermeleri gerektiğini dile getirmiştir. ${ }^{44}$

AGİT Minsk Grubu'nun eylemleri ateşkes çağrısı ve müzakere önerisinden öteye geçememiştir. Faaliyetleri boyunca "eş başkanlar sorunu çözmeye değil, çözümsüzlüğün ömrünü uzatma yönünde tavır ortaya koymuş”, "farklı çözüm arayışlarını da sürekli sabote etmiş, sorunun çözümü konusunda sadece kendilerinin yetkili olduklarına" ilişkin 1srarlı açıklamalar yapmışlardır. ${ }^{45}$ Cumhurbaşkanı İlham Aliyev'de yaptığı bir açıklamada, AGİT Minsk

42 AB Dış İlişkiler Yüksek Temsilcisi Borrell: Dağlık Karabağ için askeri müdahale söz konusu olamaz, https:// tr.euronews.com/2020/10/07/ab-den-dagl-k-karabag-uyar-s-d-s-aktorler-yalan-haberlerle-savasa-cekilmeye-cals-1-yor, 07.10.2020, (Erişim Tarihi: 16.12. 2020)..

43 Hacı Mehmet Boyraz, Oğuz Güngörmez, Karabağ Zaferinin Anatomisi, https://www.setav.org/karabag-zaferininanatomisi/, 10.12.2020, (Erişim Tarihi: 16.12. 2020); BM Güvenlik Konseyi’nden Dağlık Karabağ açıklaması, https://www.haber7.com/dunya/haber/3018955-bm-guvenlik-konseyinden-daglik-karabag-aciklamasi, 30.09.2020, (Erişim Tarihi: 16.12. 2020).

44 Betül Yürük, BM, Azerbaycan ve Ermenistan'a Dağlık Karabağ'da çatışmalara derhal son verme çağrısını yineledi, https://www.aa.com.tr/tr/azerbaycan-cephe-hatti/bm-azerbaycan-ve-ermenistana-daglik-karabagdacatismalara-derhal-son-verme-cagrisini-yineledi/1996799, 06.10.2020, (Erişim Tarihi: 16.12. 2020).

45 Ali Cura, AGİT Minsk Grubunun 28 yılda çözemediği kriz 44 günde sonlandırıldı, https://www.aa.com.tr/ tr/azerbaycan-cephe-hatti/agit-minsk-grubunun-28-yilda-cozemedigi-kriz-44-gunde-sonlandirildi/2055318, 25.11.2020, (Erişim Tarihi 08.01.2021). 
Grubu'nun fikir üretmeye yönelik faaliyetlerde bulunduğunu, fakat çatışmaların çözümünde herhangi bir rol oynamadığını dile getirmiştir. ${ }^{46}$ Savaşın bitmesinin hemen ardından temaslarda bulunmak için Bakü’ye gelen AGİT Minsk Grubu eş başkanları, Fransız Stephane Visconti, ABD'li Andrew Schofer ve AGITT Özel Temsilcisi Andrzej Kasprzyk'i, ayrıca Rusya'nın Bakü Büyükelçisi Mihail Boçarnikov’u kabul eden Cumhurbaşkanı İlham Aliyev, şöyle söylemiştir: "Ne yazık ki, Minsk Grubu çatışmanın çözümünde herhangi bir rol oynamadı ancak Minsk Grubunun 28 yıl boyunca bunu yapma yetkisi vardı. Son 17 yıldır müzakerelerin içindeyim. Minsk Grubu fikir üretmek yönünde bazl faaliyetlerde bulunsa da bunlar sonuç doğurmadı. Gerçek bu.” Gerçekten de AGiT Minsk Grubu'nun çeyrek asırdan fazla devam eden sözde barış, özde oyalama siyaseti bölgede statükoyu koruma ve işgali sürdürülebilir hale getirmeye odaklanmıştır. Azerbaycan tarafı bu siyaseti 44 devam eden Büyük Taarruz sonucunda sonlandırmıştır.

\section{AZERBAYCAN'IN ZAFERI VE STATÜKONUN SONU}

Ermenistan'ın Rusya'dan şartsız ve sürekli destek alacağına ilişkin beklentileri karşılıksız kalmıştır. Azerbaycan'ın sahadaki üstünlüğü müzakere masasında elini kuvvetlendirmiş, Ermenistan yenilgisini kabul etmiş̧tir. Onun uzun süredir uyguladığı psikolojik savaş taktiği iflas etmiştir. Bu savaşta, askeri araç, teknolojik donanım ve harp kabiliyeti bakımından Azerbaycan'ın Kafkasya'da en güçlü orduya sahip olduğu kanıtlanmış, Ermenistan’ın kendini acındırma ve mağdur edebiyatı üretme kurnazlığı hiçbir işe yaramamıştır. Savaş sırasında Azerbaycan ve Türkiye arasında, yüksek düzeyde stratejik ortaklığın gerektirdiği bir iş birliği süreci yaşanmıştır. Türkiye, jeostratejik çıkarları kapsamında yer alan Güney Kafkasya'da askeri varlığının temellerini atmıştır. ${ }^{47}$ Paşinyan'ın üçüncü unsurları savaşa çekme çabası savaş boyunca devam etmiştir. Ermenistan'ın, savaşı uluslararası alanda yankı bulacak bir düzleme taşıma, dünya ülkelerinin diplomatik desteğini, Rusya’nın, ayrıca KGAÖ’nün askeri desteğini almaya yönelik girişimleri her seferinde başarısız kalmıştır. Ermenistan yönetiminin bu planı gerçekleştirmeye yönelik çabalarını şu şekilde özetleyebiliriz:

- Yoğun şekilde sürdürülen "kara propaganda",

- İç kamuoyunda protestoları engellemek amacıyla çeşitli önlemler almak (insani ateşkese uymamak, cenazeleri almamak, "ikinci soykırım yapılacağına” dair iddiaları sürekli gündemde tutmak),

- Sivilleri vurarak Azerbaycan'1 misillemeye zorlamak,

- Türkiye’yi hedef göstermek, dünya kamuoyuna Azerbaycan ordusu, Türk ordusu ve

46 Azerbaycan Cumhurbaşkanı Aliyev: Minsk Grubu çatışmanın çözümünde herhangi bir rol oynamadı, https:// www.aa.com.tr/tr/dunya/azerbaycan-cumhurbaskani-aliyev-minsk-grubu-catismanin-cozumunde-herhangi-birrol-oynamadi/2074886, 12.12.2020, (Erişim Tarihi:08.01.2021).

47 Ali Asker, İşgalin Kırılma Noktası veya Yalancı Ateşkesin Sonu: Eylül 2020 Azerbaycan-Ermenistan Savaşını Geniş Tablodan Okumak, https://www.sde.org.tr/degerlendirme/isgalin-kirilma-noktasi-veya-yalanci-ateskesinsonu-eylul-2020-azerbaycan-ermenistan-savasini-genis-tablodan-okumak-analizi-18517, 30.09.2020, (Erişim Tarihi: 09.12.2020). 
Ortadoğu'dan gelmiş cihatçıların bir araya gelerek Ermenistan'a karşı savaştıklarına dair yalan bilgi yaymak. ${ }^{48}$

Savaş boyunca Azerbaycan halkının orduya ve yönetime yönelik kesintisiz desteği devam etmiştir. Bu destek 1990'dan bu yana Karabağ ve işgalle ilgili süreçlerin hiçbiriyle kıyaslanamayacak kadar yüksek olmuş, cephede kazanılan zaferler askerin moralini yükseltmiştir. Peş peşe gelen zafer haberlerinin getirdiği bir motivasyon ve özgüvene paralel olarak Azerbaycan yönetiminin kullandığı sert eleştirel dil; uluslararası kuruluşların ve büyük güçlerin adaletsiz, samimiyetsiz ve tarafgir tutumlarına karşı uzun süredir yalnızlığa ve mağduriyete mahkum edilmiş Azerbaycan'ın verdiği sert bir tepki olarak değerlendirilebilir. Ermenistan yönetiminin uğradığı hezimeti örtbas etme, yenilgisini içine sindirememe psikolojisi altında kendi halkını ve dünya kamuoyunu yanıltmaya devam etmişse de olumlu bir sonuç alınamamıştır. Ermenilerin kara propagandası sadece Azerbaycan ordusunu değil, Türk ordusunu da hedef almıştır. Ermenistan ordusunun sadece Türkiye ve Azerbaycan ordularına değil, Ortadoğu'dan getirilmiş terör unsurları ve paralı yabancı savaşçılara karşı da mücadele ettiğine dair saçmalıkları herhangi bir şekilde karş1lık bulmamıştır. Keza Azerbaycan otuz sene boyunca Ermeniler tarafindan sürekli güçlendirilen istihkâm ve siperlerin bulunduğu Karabağ'ın işgal edilmiş bölgelerini kısa sürede geri alarak adeta dünyayı hayrete düşürmüştür. Azerbaycan Cumhurbaşkanı İlham Aliyev, savaş bittikten sonra yaptığı bir açıklamada şunları söylemiştir: "Biz aslında Sarkisyan ve Koçaryan' yendik. Onlar tüm sorumluluğu Paşinyan'ın üzerine atmak istiyorlar. Daha önce de söyledim. Paşinyan kim ki. O, Sarkisyan ve Koçaryan rejimine karşı protesto dalgasında iktidara gelen rastgele bir adam. Bu kişinin hiçbir bilgisi veya deneyimi yoktur. Uluslararası ilişkiler ve ülke yönetimi hakkında hiçbir fikri yok. Hayatında hiçbir zaman yöneticilik yapmamış bir adam. Yani tek başına suçlanamaz. Bizi kışkırttığı, kabul edilemez şeyler yaptı̆̆ ordusunu yendik. " 49

Böylece, 44 gün devam eden savaşın sonunda Ermenistan ordusu işgal ettiği Azerbaycan topraklarından atılmış, eskiden sıkça kullanılan ve istismar edilen "temas hattı", "ateşkes", “çözüm süreci” ve "statüko" gibi kavramlar dolaşımdan kalkmış, Ermenistan bu savaştaki yenilgisini kabullenmek zorunda kalmıştır. Gerek tarihi, kültürel ve manevi, gerekse stratejik açıdan Azerbaycan için büyük önem arz eden Şuşa şehrinin alınmasının ardından, muhtemelen tertiplenen bir helikopter olayı sonrası akıllara gelen ilk şey Rusya'nın duruma askeri anlamda müdahale edip edemeyeceği sorusuydu. 9 Kasım 2020 tarihinde Moskova saati ile 17.30 civarında 102. Rus askeri üssüne ait bir konvoya eşlik eden Mi-24 tipi Rus askeri helikopteri Ermenistan'ın Yeraskh yerleşim birimi yakınında, Nahçıvan sınırına yakın bölgede roketatarla

48 Ali Asker, Başarısız Hamle: Paşinyan'ın Mektubu, https://kafkassam.com/basarisiz-hamle-pasinyanin-mektubu. html, 01.11.2020, (Erişim Tarihi: 09.12.2020).

49 Azerbaycan Cumhurbaşkanı Aliyev: Minsk Grubu çatışmanın çözümünde herhangi bir rol oynamadı, https:// www.aa.com.tr/tr/dunya/azerbaycan-cumhurbaskani-aliyev-minsk-grubu-catismanin-cozumunde-herhangi-birrol-oynamadi/2074886, 12.12.2020, (Erişim Tarihi:08.01.2021). 
vurularak Ermenistan sınırları içinde dağlık bir alan düşürülmüş ve olayda mürettebattan iki kişi hayatını kaybetmiştir. Azerbaycan tarafından bu olayla ilgili yapılan açıklamada “Azerbaycan, yanlışlıkla yapılan ve Rusya'ya yönelik olmayan bu trajik olay için Rusya'dan özür diliyor. Azerbaycan tarafı, hayatını kaybeden mürettebatın ailelerine en derin taziye dileklerini iletiyor, yaralılara acil şifalar diliyor" şeklinde ifadeler yer almıştır. ${ }^{50}$ Aynı gece Bakü'de bir balistik füzenin savunma sistemi tarafından imha edildiğine dair bilgiler haber ajansları tarafından duyurulmuştur. Böyle bir ortamda, Azerbaycan ve Ermenistan arasında imzalanan Üçlü Bildiriyle 10 Kasım 2020 tarihinde, Moskova saatiyle 00:00'den itibaren tüm çatışmalara tam ateşkes rejimine geçilerek son verildiği Azerbaycan Cumhurbaşkanı İlham Aliyev tarafından açıklamıştır. Aliyev anlaşmanın maddelerini tek tek açıklamış ve bu siyasi zaferin kazılmasında askerî başarının önemli bir rolü olduğunu belirtmiştir. ${ }^{51}$ İlham Aliyev, bu belgenin Ermenistan açısından askeri yenilginin bir ifadesi, sorunun çözümü hususunda "son nokta" olacağını belirtmiştir. ${ }^{52}$ Yine bu konuda Cumhurbaşkanları Erdoğan ve Aliyev arasında bir telefon görüşmesi gerçekleşmiş ve taraflar kazanılan zafer münasebetiyle birbirlerini tebrik etmişlerdir. Aliyev, verdikleri manevi ve siyasi destekten dolayı Cumhurbaşkanı Erdoğan'a ve Türk milletine teşekkür etmiştir. ${ }^{53}$ Olayı duyan Ermeniler parlamento binasını basarak, Paşinyan'ın istifasını talep etmişlerdir. Anlaşma gereği Azerbaycan, Dağlık Karabağ' da geri aldığı bölgeler üzerinde kontrolü ele almış ve Ermenistan ordusu işgal ettiği bölgelerden geri çekilmek zorunda kalmış, Laçin koridoru üzerindeki kontrol Rus Barış Gücü’ne, Azerbaycan'ın anakarasıyla Nahçıvan'ı bağlayan yolun kontrolü ise Rus federal güvenlik güçlerine devredilmiştir.

Büyük ölçüde Azerbaycan'ın çıkarlarını karşılayan bu bildiri metninde bazı belirsizliklerin olduğunu özellikle vurgulamak gerekir. Rus Barış Gücü'nün bundan sonraki süreçte nasıl bir tutum sergileyeceği ciddi merak doğurmaktadır. İlerleyen süreçte, Batılı devletler ve Rusya'nın desteği ile bölgede yaşayan Ermeniler için bir özerklik talebi getirilme getirilebilir. Azerbaycan'ın bu konudaki duruşu asla değişmemeli ve 1991'de Dağlık Karabağ'ın özerklik statüsünü kaldıran kararından ${ }^{54}$ geri dönülmemelidir.

50 Ali Cura, Ruslan Rehimov, Ermenistan'da Rus askeri helikopteri düşürüldü: 2 ölü, https://www.aa.com.tr/tr/ azerbaycan-cephe-hatti/ermenistan-da-rus-askeri-helikopteri-dusuruldu-2-olu/2037638, 09.11.2020, (Erişim Tarihi: 14.12.2020).

51 Tarihi an ve tarihi açıklama! Aliyev madde madde açıkladı, https://haberglobal.com.tr/dunya/tarihi-an-ve-tarihiaciklama-aliyev-madde-madde-acikladi-77808, 10.11.2020, (Erişim Tarihi: 09.01.2021).

52 Son dakika: Paşinyan savaşı kaybettiklerini açıkladı, Aliyev belgeyi gösterdi ve bu sözlerle zaferi ilan etti, 'Ağlaya ağlaya imzalayacak!', https://www.hurriyet.com.tr/galeri-son-dakika-pasinyan-savasi-kaybettiklerinibu-sozlerle-acikladi-cok-aci-verici-ermenistan-yenilgiyi-kabul-etti-azerbaycanda-buyuk-sevinc-41658657/1, 10.11.2020, (Erişim Tarihi: 09.12.2020).

53 Erdoğan ile Aliyev görüştü, https://haberglobal.com.tr/gundem/erdogan-ile-aliyev-gorustu-77860, 10.11.2020, (Erişim Tarihi: 09.12.2020).

54 “Azərbaycan Respublikasının Dağlıq Qarabağ Muxtar Vilayətini ləğv etmək haqqında” Azərbaycan Respublikası Qanununun qüvvəyə minməsi qaydası barəsində Azərbaycan Respublikasi Ali Sovetinin qərari, http://www.eqanun.az/framework/6784, 26 noyabr 1991-ci il, (Erişim Tarihi: 09.12.2020). 


\section{SONUÇ}

Azerbaycan-Ermenistan arasındaki savaşın ateşkes dönemi Azerbaycan ordusunun 27 Eylül 2020'de Ermenistan ordusunun saldırısına karşı başlattığı taarruz sonucunda nihai olarak sona ermiştir. 44 gün devam eden savaş boyunca Ermenistan büyük kayıplar vermiş, yenilgisini kabul ederek işgal ettiği topraklardan çekilmek zorunda kalmıştır. Böylece sürekli olarak dile getirilen statüko olgusu sona ermiştir.

Bu savaş boyunca Ermenistan her zaman kendisine destek veren büyük güçlerin, özellikle Rusya, Fransa ve ABD’nin kapısını aşındırmış, başta BM olmakla uluslararası kuruluşlara müracaat ederek Azerbaycan'a ve Türkiye'ye karşı yaptırım talebinde bulunmuştur. Bu talebe karşılık, Rusya savaşın Ermenistan'da değil, Azerbaycan topraklarında devam ettiğini, bu yüzden herhangi bir aktif müdahalede bulunamayacağını açıklarken, BM de sorunun AGİT Minsk Grubu tarafından yürütülen barış süreci kapsamında çözülmesi gerektiğine işaret etmiştir. Başkanlık seçimleriyle uğraşan ABD yönetimi de soruna kayıtsız kalmıştır. Sadece Fransa sonuna kadar Ermenistan'ın yanında yer alsa da bu destek diplomasiyle sınırlı kalmıştır.

Savaş boyunca Azerbaycan'da halk-ordu dayanışması son derece sağlıklı biçimde yürümüş, Azerbaycan halkı yüksek vatanseverlik ruhu, kararlılık ve galebe azmi sergilemiştir. Cephede büyük zayiat veren Ermenistan, sürekli kara propaganda yaparak, yalan bilgi üreterek ve asılsız suçlamalarda bulunarak dünya kamuoyunu ve kendi halkını aldatarak zaman kazanmaya çalışmış, bu zaman zarfında üçüncü güçleri savaşa çekerek olayların seyrini değiştirmeye çalışmıştır. Fakat bu konudaki beklentileri gerçekleşmemiş, asker, silah ve mühimmat yönünden kayıpları her geçen gün artmış, Şuşa şehrinin Azerbaycan ordusu tarafından geri alınmasının ardından çaresiz kalarak yenilgiyi kabullenmiştir. 10 Kasım 2020'de Rusya'nın öncülüğünde yapılan Üçlü Bildiri, savaşı durdururken Ermenistan güçlerinin Azerbaycan topraklarından çekilmesini takvime bağlamıştır. Bu anlaşmaya göre Ermenistan ordusu 15 Kasım'da Kelbecer'den, 20 Kasım'da Ağdam'dan ve 1 Aralık'ta Laçın'dan çekilmeyi kabul etmiştir. Sonradan Kelbecer'den çekilme süreci 25 Kasım'a kadar uzatılmıştır. Ermeni ordusunun yanı sıra işgal edilmiş topraklarda bulunan Ermeni yerleşimciler de bölgeyi terk ederek taşıyabildikleri kadar eşya, inşaat malzemesi, odun, hayvan yemi vs. kamyonlarla Ermenistan'a taşımış, geride bıraktıkları evleri ve ormanları ateşe vermişlerdir.

Üçlü Bildiri sayesinde Ermenistan işgal ordusu tam olarak imha edilmekten kurtulmuş, Rus ordusu “Barış Gücü” statüsünde Karabağ bölgesine konuşlanmış, Azerbaycan'ın yukarıda ismi geçen bölgeleri savaş yapılmadan geri alınmıştır. Ayrıca, bildiri metninde geçmese de bölgede kurulacak Gözlem Merkezi'nde Türkiye'nin de yer alacağı konusunda anlaşmaya varılmıştır. Bildiri metninde Nahçıvan'ın Azerbaycan anakarasıyla bağlantısının tesis edileceği konusunda bir hükme yer verilmesi Azerbaycan, Türkiye ve Rusya açısından olumlu bir adım olarak değerlendirilmiştir. Dolayısıyla Üçlü Bildiri’nin imzalanması tarafların her birine belli kazanımlar sağlarken, Azerbaycan açısından psikolojik-manevi anlamda önemli bir gelişme olarak değerlendirilebilir. Keza otuz yıldır “yenilmişliğin” baskısı altında kalan Azerbaycan bu savaşı, bir galip olarak tamamlamıştır. 
Bundan sonraki süreçte yaşanacak olayların seyrini tahmin etmek çok da kolay değildir. Fakat bölgede Rusya'nın etkin söylemlerine uygun bir barış sürecinin başlayacağı ihtimali yüksektir. Azerbaycan'ın, ulusal çıkarları doğrultusunda hareket etmesi, gelişen olayları dikkatle takip etmesi, süreci Rusya ile diyalog ve Türkiye ile yakın iş birliği içinde yürütmesi barış sürecinde dikkate alınması gereken önemli hususlardır. Üçlü Bildiri'nin getirdiği barış süreci şüphesiz ki Azerbaycan halkını tam memnun etmemiştir. Rusya'nın Kafkasya bölgesinde iki yüz yıldan fazla devam eden sömürge politikası doğrultusunda belirlediği stratejisi ve uyguladığı taktikleri şeklen değişse de mazmun bakımından pek değişmemiştir: bölgenin demografik yapısını bozmak, askeri güç konuşlandırmak için bahane uydurmak (çatışma çıkarmak), bölgeye yerleşerek kalıcı olmaya çalışmak. Azerbaycan'ın bu politikalara karşı koyması sadece Türkiye ile geliştirilecek birliktelik sayesinde mümkün olacaktır.

Hakem Değerlendirmesi: Dış bağımsız.

Çıkar Çatışması: Yazarlar çıkar çatışması bildirmemiştir.

Finansal Destek: Yazarlar bu çalışma için finansal destek almadığını beyan etmiștir.

Peer-review: Externally peer-reviewed.

Conflict of Interest: The authors have no conflict of interest to declare.

Grant Support: The authors declared that this study has received no financial support.

\section{Kaynakça/References}

“Azərbaycan Respublikasının Dağlıq Qarabă̆ Muxtar Vilayətini ləğv etmək haqqında” Azərbaycan Respublikası Qanununun qüvvəyə minməsi qaydası barəsində Azərbaycan Respublikasi Ali Sovetinin qərari, http:// www.e-qanun.az/framework/6784, 26 noyabr 1991-ci il, (Erişim Tarihi: 09.12.2020).

AB Dış İlişkiler Yüksek Temsilcisi Borrell: Dağlık Karabağ için askeri müdahale söz konusu olamaz, https:// tr.euronews.com/2020/10/07/ab-den-dagl-k-karabag-uyar-s-d-s-aktorler-yalan-haberlerle-savasa-cekilmeyecal-s-1-yor, 07.10.2020, (Erişim Tarihi: 16.12. 2020).

Aliyev'den Fransa'ya: Çok istiyorsanız Marsilya'yı Ermenilere verin, orada devlet kursunlar, https://tr.euronews. com/2020/12/01/aliyev-den-fransa-ya-cok-istiyorsan-z-marsilya-y-ermenilere-verin-orada-devlet-kursunlar, 01.12.2020, (Erişim Tarihi: 08.01.2021).

Aprel döyüşləri - böyük zəfərin başlanğıc1, https://mod.gov.az/az/pre/21662.html, 17.02.2018, (Erişim Tarihi: 09.12.2020).

Aras İlhan, “Avrupa Birliği’nin Dağlı Karabağ Sorunundaki Rolü”, Avrasya Etüdleri, 51/2017-1 (ss. 95-122).

Asker Ali, 10 Ekim 2020 Tarihli Ateşkes veya "Masa Tuzağı", https://kafkassam.com/10-ekim-2020tarihli-ateskes-veya-masa-tuzagi.html?fbclid=IwAR0rplY fDcEPE8Hgt fs 148Vg3HSOwY2GiQ7BA0FQ11hn0BfK1UEW6Zy3I, 10.10.2020, (Erişim Tarihi: 09.12.2020).

Asker Ali, Afgan Bakhshaliyev, "Rusya'nın Kafkasya Politikasında Karabağ Faktörü”, I. Uluslararası Sovyet Sonrası Türkiye-Rusya İlişkileri Sempozyumu, 15-16 Ekim 2020, Ege Üniversitesi Türk Dünyası Araştırmaları Enstitüsü, İzmir 2020 (ss. 49-59).

Asker Ali, Başarısız Hamle: Paşinyan'ın Mektubu, https://kafkassam.com/basarisiz-hamle-pasinyanin-mektubu. html, 01.11.2020, (Erişim Tarihi: 09.12.2020). 
Asker Ali, Doç. Dr. Asker: Kremlin'den Umduğunu Bulamayan Paşinyan Çaresiz Bir Şekilde Yenilgiyi Seyrediyor, https://qha.com.tr/haberler/doc-dr-asker-kremlin-den-umdugunu-bulamayan-pasinyan-caresizbir-sekilde-yenilgiyi-seyrediyor/255810/, 08.10.2020, (Erişim Tarihi: 09.12.2020). [Söyleşi]

Asker Ali, İşgalin Kırılma Noktası veya Yalancı Ateşkesin Sonu: Eylül 2020 Azerbaycan-Ermenistan Savaşını Geniş Tablodan Okumak, https://www.sde.org.tr/degerlendirme/isgalin-kirilma-noktasi-veya-yalanciateskesin-sonu-eylul-2020-azerbaycan-ermenistan-savasini-genis-tablodan-okumak-analizi-18517, 30.09.2020, (Erişim Tarihi: 09.12.2020).

Azerbaycan Cumhurbaşkanı Aliyev: Minsk Grubu çatışmanın çözümünde herhangi bir rol oynamadı, https:// www.aa.com.tr/tr/dunya/azerbaycan-cumhurbaskani-aliyev-minsk-grubu-catismanin-cozumunde-herhangibir-rol-oynamadi/2074886, 12.12.2020, (Erişim Tarihi:08.01.2021).

Azerbaycan Cumhurbaşkanı Aliyev'den sivil yerleşimleri hedef alan Ermenistan'a tepki: Faşist devlet, https:// www.haberler.com/azerbaycan-cumhurbaskani-aliyev-ermenistan-fasist-13423804-haberi/, 15.07.2020, (Erişim Tarihi: 13.03.2021).

Balcı Çağatay, İran’ın Karabağ propagandası neden başarısız oldu, https://www.aa.com.tr/tr/analiz/iran-inkarabag-propagandasi-neden-basarisiz-oldu/2027725, 02.11.2020, (Erişim Tarihi: 14.12.2020).

BM Güvenlik Konseyi'nden Dağlık Karabağ açıklaması, https://www.haber7.com/dunya/haber/3018955-bmguvenlik-konseyinden-daglik-karabag-aciklamasi, 30.09.2020, (Erişim Tarihi: 16.12. 2020).

Boyraz Hacı Mehmet, Avrupa’nın Dağlık Karabağ Tutumu, https://www.setav.org/avrupanin-daglik-karabagtutumu/, 04.12.2020, (Erişim Tarihi: 09.12.2020).

Boyraz Hacı Mehmet, Güngörmez Oğuz, Karabağ Zaferinin Anatomisi, https://www.setav.org/karabagzaferinin-anatomisi/, 10.12.2020, (Erişism Tarihi: 16.12. 2020).

Boyraz Turgut Alp, Ahıshalı Mustafa Melih, İran yönetiminin Dağlık Karabağ konusundaki tutumu ne, https://www.aa.com.tr/tr/a.zerbaycan-cephe-hatti/iran-yonetiminin-daglik-karabag-konusundaki-tutumune/1998888, 07.10.2020, (Erişim Tarihi: 08.01.2021).

Caferov Nazim, Aslanlı Araz, "Karabağ Sorununda Ateşkes ve Rusya”, Ermeni Araştırmalarl, 2016, Sayı: 53 (ss. 239-260).

Cafersoy Nazim, “4 Gün Savaşı” ve Bölgesel Dengeler, https://www.dw.com/tr/4-gün-savaş-ve-bölgeseldengeler/a-19168839, 06.04.2016, (Erişim Tarihi: 09.12.2020).

Cumhurbaşkanı Erdoğan: Bu saldırı Ermenistan'ın çapını aşan bir hadisedir, https://qha.com.tr/haberler/ guncel/cumhurbaskani-erdogan-bu-saldiri-ermenistan-in-capini-asan-bir-hadisedir/224116/, 14.07.2020, (Erişim Tarihi: 13.03.2021).

Cura Ali, AGİT Minsk Grubunun 28 yılda çözemediği kriz 44 günde sonlandırıldı, https://www.aa.com.tr/tr/ azerbaycan-cephe-hatti/agit-minsk-grubunun-28-yilda-cozemedigi-kriz-44-gunde-sonlandirildi/2055318, 25.11.2020, (Erişim Tarihi 08.01.2021).

Cura Ali, Rehimov Ruslan, Ermenistan'da Rus askeri helikopteri düşürüldü: 2 ölü, https://www.aa.com.tr/ tr/azerbaycan-cephe-hatti/ermenistan-da-rus-askeri-helikopteri-dusuruldu-2-olu/2037638, 09.11.2020, (Erişim Tarihi: 14.12.2020).

Çavuşoğlu'ndan Karabağ açıklaması: Artık bu meseleyi kökünden çözmek istiyoruz, https://www.haberturk.com/ cavusoglu-ndan-karabag-aciklamasi-artik-bu-meseleyi-kokunden-cozmek-istiyoruz-2818652, 29.09.2020, (Erişim Tarihi: 12.03.2021).

Dağlık Karabağ: Ermenistan Türkiye'yi çatışmalarda Azerbaycan'a askeri destek vermekle suçladı, https:// www.bbc.com/turkce/haberler-dunya-54315251, 28.09.2020, (Erişim Tarihi: 12.03.2021). 
Erdoğan ile Aliyev görüştü, https://haberglobal.com.tr/gundem/erdogan-ile-aliyev-gorustu-77860, 10.11.2020, (Erişim Tarihi: 09.12.2020).

Güler Mehmet Çağatay, 5 Soru: Dağlık Karabağ Çatışması: Azerbaycan-Ermenistan İlişkilerinde Bir Kırılma m1, https://www.setav.org/5-soru-daglik-karabag-catismasi-azerbaycan-ermenistan-iliskilerinde-bir-kirilmami/, 29.09.2020, (Erişim Tarihi: 09.12.2020).

Güler Mehmet Çağatay, Karabağ'nn Özgürleştirilmesi ve Sahadaki Yeni Denklem, https://www.setav.org/ perspektif-karabagin-ozgurlestirilmesi-ve-sahadaki-yeni-denklem/, 11.10.2020, (Erişim Tarihi: 16.12.2020).

Keskin Arif, İran'ın Karabağ Siyasetinin 5 Yüzü, https://fikirturu.com/jeo-strateji/iranin-karabag-siyasetinin5-yuzu/, 12.10.2020, (Erişim Tarihi: 16.02. 2021).

Kılavuz İdil Tunçer, “Dağlık Karabağ Müzakerelerinin Geleceği”, Avrasya Etütleri, Sayı: 52 (2017) (ss. 51-78).

Mahmudova Gülnare, “Arabuluculuk Diplomasisi Bağlamında AGİT Minsk Grubu’nun Başarısız Eylemi Başarılı Söylemi: Dağlık Karabağ Sorununa İlişkin 2-5 Nisan 2016 Tarihleri Arasındaki Açıklamaların Söylem Çözümlemesi”, TURAN-SAM Uluslararası Bilimsel Hakemli Dergisi, Sayı: 42 (2019) (ss. 207-215).

Milli Savunma Bakanı Hulusi Akar'dan Fransa'ya sert tepki: Herkesin efelik yapacă̆ı bir ülke olmadığımızı görsünler, https://www.takvim.com.tr/guncel/2020/07/17/milli-savunma-bakani-hulusi-akardan-fransayasert-tepki-herkesin-efelik-yapacagi-bir-ulke-olmadigimizi-gorsunler, 17.07.2020, (Erişim Tarihi: 10.02.2021).

No: 149, 12 Temmuz 2020, Azerbaycan'a Yönelik Ermeni Saldırıs1 Hk., https://web.archive.org/ web/20200712222134/http://www.mfa.gov.tr/no_-149_-azerbaycan-a-yonelik-ermeni-saldirisi-hk.tr.mfa, (Erişim Tarihi: 10.02.2021).

No: 300, 26 Kasım 2020, Fransa Senatosu'nun Yukarı Karabağ İhtilafına İlişkin 25 Kasım 2020 Tarihinde Kabul Ettiği Karar Hk. http://www.mfa.gov.tr/no_-300_-fransa-senatosu-nun-yukari-karabag-ihtilafinailiskin-karari-hk.tr.mfa, 26.11.2020, (Erişim Tarihi: 09.12.2020).

Rehimov Ruslan, Ermenistan, Türkiye ve Azerbaycan'ın ortak projelerinin bulunduğu bölgede saldırı düzenliyor, https://www.aa.com.tr/tr/dunya/ermenistan-turkiye-ve-azerbaycanin-ortak-projelerinin-bulundugu-bolgedesaldiri-duzenliyor/1913508, 17.07.2020, (Erişim Tarihi: 10.12.2020).

Sadıgov Ramin, Ermenistan'ın son saldırısı nasıl okunmalı?, https://fikirturu.com/jeo-strateji/ermenistaninson-saldirisi-nasil-okunmali/, 22.07.2020, (Erişim Tarihi: 10.12.2020).

Son dakika haberi: TBMM Başkanı Mustafa Şentop'tan flaş açıklamalar, https://www.hurriyet.com.tr/gundem/ son-dakika-haberi-tbmm-baskani-mustafa-sentoptan-flas-aciklamalar-41640812, 20.10.2020, (Erişim Tarihi: 12.03.2021).

Son dakika: Paşinyan savaşı kaybettiklerini açıkladı, Aliyev belgeyi gösterdi ve bu sözlerle zaferi ilan etti, 'Ağlaya ağlaya imzalayacak!', https://www.hurriyet.com.tr/galeri-son-dakika-pasinyan-savasi-kaybettiklerini-busozlerle-acikladi-cok-aci-verici-ermenistan-yenilgiyi-kabul-etti-azerbaycanda-buyuk-sevinc-41658657/1, 10.11.2020, (Erişim Tarihi: 09.12.2020).

Tarihi an ve tarihi açıklama! Aliyev madde madde açıkladı, https://haberglobal.com.tr/dunya/tarihi-an-ve-tarihiaciklama-aliyev-madde-madde-acikladi-77808, 10.11.2020, (Erişim Tarihi: 09.01.2021).

TBMM'de 4 partiden Fransa Senatosu'nun skandal Dağlık Karabağ kararına kınama, https://www.haberler. com/tbmm-de-4-partiden-fransa-senatosu-nun-skandal-13763928-haberi/, 27.11.2020, (Erişim Tarihi: 09.12.2020).

Tuncel Turgut Kerem, Karabağ'da Yaşanan “4 Gün Savaşı”nın Kısa Bir Değerlendirmesi. Yorum No: 2016/21, https://avim.org.tr/tr/Yorum/KARABAG-DA-YASANAN-4-GUN-SAVASI-NIN-KISA-BIRDEGERLENDIRMESI, 14.04.2016, (Erişim Tarihi: 18.01.2021). 
Tuncel Turgut Kerem,’Güney Kafkasya'da 2-5 Nisan 2016'da Yaşanan 4 Gün Savaşı”, Ermeni Araştırmaları, Say1: 53 (2016) (ss. 301-338).

United Nations Security Council, Resolution 822, 30 April 1993; United Nations Security Council, Resolution 853, 29 July 1993; United Nations Security Council, Resolution 874, 14 October 1993; United Nations Security Council, Resolution 884, 12 November 1993. United Nations, "Security Council Resolutions -1993”, https://2001-2009.state.gov/p/eur/rls/or/13508.htm, (Erişim Tarihi:08.01.2021).

Yürük Betül, BM, Azerbaycan ve Ermenistan'a Dağlık Karabağ’da çatışmalara derhal son verme çağrısını yineledi, https://www.aa.com.tr/tr/azerbaycan-cephe-hatti/bm-azerbaycan-ve-ermenistana-daglik-karabagdacatismalara-derhal-son-verme-cagrisini-yineledi/1996799, 06.10.2020, (Erişim Tarihi: 16.12. 2020). 